JP3I (Jurnal Pengukuran Psikologi dan Pendidikan Indonesia), 9(2), 2020, I2-43

D0l: http://dx.doi.org/10.15408/p33iv9i2.XXXXX

http://journal.uinjkt.ac.id/index.php/jp3i

\title{
Assessing Lecturer's Understanding of Plagiarism: A Case in Indonesia
}

\author{
Diah Wihardini \\ Department of Mathematics, School of Computer Science, Bina Nusantara University, Indonesia \\ dwihardini@binus.edu
}

\begin{abstract}
Plagiarism, a concept of intellectual property in academic writing, has gained importance during the past few years in Indonesian higher education system. The vague definition and understanding of plagiarism have seemed to induce inconsistent efforts in preventing plagiarism practices in the local tertiary institutions (Akbar \& Picard, 2019). This study aims to introduce and describe the step-by-step process in developing an assessment instrument that can measure a university lecturer's understanding of plagiarism concept. A Rasch's partial credit model was used in the data analysis to explain the different levels of the hypothesized understanding of plagiarism construct. Not only that the findings can help ones to learn the necessary steps to develop the instrument that upholds standards of reliability and validity, they can also provide good insights for the university authority to set an appropriate training for the lecturers on plagiarism prevention and mitigation as the different levels of these lecturers' understanding of plagiarism are unpacked and addressed.
\end{abstract}

Keywords: plagiarism, construct development, assessment, measurement instrument, Rasch model, validity, reliability. 


\section{Introduction}

As a form of academic misconduct, plagiarism has cautioned higher education institutions in developing countries, especially those who are building international reputation (MacDonald \& Carroll, 2006; Akbar \& Picard, 2019). Sardjono (2006) and Adiningrum (2008) indicate that the understanding of the concept has not been fully accommodated in Indonesian academic culture due to the difference in valuing intellectual property between the Indonesian academicians and their Western counterparts. The concept of intellectual property did not exist in the traditional Indonesian community, rather it was introduced and developed by the Western countries which put economic and culture interests on Indonesia, starting from the Dutch colonial government in the 1800s and then, the United States of America government and European Union in the 1980s (Kusumadara, 2008). The notion of plagiarism itself has not been nationally considered as important and serious violation of intellectual property right until the emergence of the Ministry of Education decree on deterring and overcoming plagiarism in higher education institutions, i.e. Permendiknas No. 17 in 2010 (Kemendiknas, 2010). However, Akbar and Picard (2019), through their intensive discourse analysis on the existing policies in Indonesia higher education institutions, have suggested that there is a need to define plagiarism among the institutions in "a contextually relevant way" (p. 15). The different interpretations on the degree of violations have made the university authorities relax the penalties/sanctions on plagiarism practices. Hence, defining ways in which the concept of plagiarism can be understood by the teaching faculty of lecturers are deemed important before a good policy on plagiarism prevention and mitigation can be determined.

The current study intends to continue an internal research project conducted in a private tertiary education institution in Jakarta (Indonesia), which was aimed at exploring the academic staff's understanding of plagiarism and how it affected assessment activities in an Indonesian higher education institution. In the previous study, a series of focus group discussions (FGD) with lecturers, management, and students at an international program of the institution was conducted to portray how important plagiarism was for the institution and whether the lecturers had sufficient understanding of plagiarism and willingness to implement the principles of anti-plagiarism in their assessment designs. It yielded somewhat contradictory findings that there was a discrepancy of understanding of plagiarism between the staff (Adiningrum, Wihardini, \& Warganegara, 2011).

The International Undergraduate Program (IUP) offers a number of single and double degrees, in which the latter are conferred by partner universities abroad. English is, therefore, the only formal language of instruction. Like in many other private universities in Indonesia, the IUP employs only a handful of full-time academics who acts as both lecturers and managers of different departments within the program, and hires professionals or industry practitioners to teach in part-time basis since these professionals are expected to bring in their work experience, expertise, and insights into the classroom teaching. These part-time lecturers normally spend time at the institution only during their teaching hours due to their other work arrangement. Having conducted focus group discussions (FGDs) with staff, the past qualitative study finds that although most lecturers were fully aware of the concept, the part-time lecturers had not been fully informed about the anti-plagiarism campaign and policy (Adiningrum, Wihardini, \& Warganegara, 2011). Meanwhile, the full-time staff suggested that the reinforcement of the policy was not optimal. Also, the FGD participants had not seemed to have a full comprehension of the technicalities, i.e. determining what practices would be considered as plagiarism, performing appropriate paraphrasing and referencing, and detecting plagiarized texts. In addition, the staff perceptions that antiplagiarism principles had been factored in their teaching, learning, and assessment activities were not fully supported as students reported that the concept had not been reinforced enough in class. Furthermore, the actual reporting of plagiarism misconduct was low and the detection facility available had not been used to its full potential (Adiningrum, Wihardini, and Warganegara, 2011). 
Since lecturers as faculty member played an important role in fostering academic integrity, they should advocate the applications and practices of anti-plagiarism principles at their best (Whitley \& KeithSpiegel, 2001). Otherwise, students would not be able to uphold the concept. Therefore, the need to better assess the level of understanding of the plagiarism concept of every individual lecturer and how well they have implemented the anti-plagiarism principles in the institution has emerged in order to better assist students in avoiding plagiarism practices and promote internationally-accepted academic culture in Indonesia.

This study is designed as a pilot study that uses a survey-design method with Item Response Theory to measure the lecturer's level of understanding of plagiarism concept. It attempts to answer the following questions:

(1) To what extend can the concept be hypothesized as a progression of levels of understanding of plagiarism?

(2) To what extent can the assessment instrument provide a valid and reliable measure on the understanding of plagiarism construct?

For a pilot study, the survey was distributed to lecturers teaching in business- and management-related courses. The findings of the study would inform how a valid and reliable instrument can be developed to assess the level of understanding of plagiarism. The outcomes can then give an informed knowledge to the program's policy makers about their faculty's level of understanding of the concept, which will also be useful to design a better professional development in promoting anti-plagiarism principles and enhancing good practices of academic integrity. In the long run, once this survey has reached a wider audience to lecturers throughout Indonesia, it might be useful to assist in the development of national policy on anti-plagiarism code of conduct, which is currently unavailable.

\section{Methods}

\section{Construct Development}

Among many survey-designed studies conducted on the plagiarism issues, two past research have contributed to the development of the framework for this study, i.e. research done by Robinson-Zanartu and her colleagues (2005) and Wilkinson (2009). Robinson-Zanartu and her team examined how faculty members perceived the severity of plagiarism and recommended responses given several case scenarios (Robinson-Zanartu, Pena, Cook-Morales, Pena, Afshani, Nguyen, 2005). They found that the perceptions on how severe plagiarism practices were conducted would influence how response and punishment needed to be executed. Meanwhile, Wilkinson (2009) administered a set of survey to both teaching staff and students to measure their attitudes toward plagiarism and cheating and investigate the differences. It was indicated that the difference in the perception of the staff's guidance for plagiarism check on students' work might cause plagiarism practices to occur among the students. Therefore, a similar, if not the same, level of understanding of plagiarism concept among staff is deemed necessary to enable them giving the same message to students on how to avoid plagiarism.

For the purpose of the current study, a construct called "Understanding of Plagiarism (UP)" was developed to measure the level of understanding of the plagiarism concept. The construct and its corresponding levels would guide the development and analysis of the survey items according to the item response theory (Wilson, 2005). A graphical representation of this construct can be found in Figure 1. At the lowest level shown in Error! Reference source not found., it attempts to assess the awareness of the concept by examining whether or not the participant knows about the notion of plagiarism and its definition at the basic level. This is considered necessary as there might be some participants who are not aware of the terminology due to the exposure to different academic culture. Next, an understanding that 
plagiarism is an aspect of internationally accepted academic culture is measured. The level of understanding will then increase when the participant is able to identify some plagiarism activities, as they are commonly stated in the student or faculty guidelines. Furthermore, an understanding of the concepts of paraphrasing and referencing is also considered as an enhancement of the understanding of plagiarism. Finally, the highest level of understanding might be shown by an awareness of some antiplagiarism principles and techniques to avoid plagiarism activities. The awareness of anti-plagiarism principles may range from some knowledge on performing appropriate paraphrasing and referencing, determining what penalties can be imposed to a detected plagiarism practice, the use of available plagiarism detection software, and on the applications of the principles.

\begin{tabular}{|c|c|c|}
\hline $\begin{array}{l}\text { Levels of } \\
\text { Construct }\end{array}$ & $\begin{array}{l}\text { Increasing } \\
\text { level of } \\
\text { understanding }\end{array}$ & $\begin{array}{l}\text { Construct Description } \\
\text { When reaching this level, a respondent can }\end{array}$ \\
\hline Exemplary & & $\begin{array}{l}\text { Have a full comprehension of the concept of plagiarism, } \\
\text { paraphrasing and referencing, and awareness of anti-plagiarism } \\
\text { principles and activities }\end{array}$ \\
\hline High & & $\begin{array}{l}\text { Have a full comprehension of the concept of plagiarism } \\
\text { Can detect and identify high level of plagiarism practices }\end{array}$ \\
\hline Satisfactory & & $\begin{array}{l}\text { Have some knowledge of paraphrasing and referencing } \\
\text { Understand that it violates internationally accepted academic } \\
\text { culture } \\
\text { Can identify more than one plagiarism practices }\end{array}$ \\
\hline Low & & $\begin{array}{l}\text { Can identify one plagiarism practice } \\
\text { Know the definition of plagiarism }\end{array}$ \\
\hline $\begin{array}{l}\text { Very low/ } \\
\text { None }\end{array}$ & & No awareness of the notion of plagiarism \\
\hline & $\begin{array}{l}\text { Decreasing } \\
\text { level of } \\
\text { understanding }\end{array}$ & \\
\hline
\end{tabular}

Figure 1. A Sketch of the Construct Map for the Lecturer's Understanding of Plagiarism

\section{Survey Development}

The Understanding of Plagiarism Survey (UPS) instrument consists of two parts. The first part (28 items) assesses the understanding of the concept, while the second part asks external demographic variables such as gender, age, education background, teaching status, and English competency. These external variables are used for a post-analysis to examine how they associate with the level of understanding. In order to ensure that the instrument can represent the construct consistently and give stable outcome, it uses the Alternate-Form reliability measure in which contains 2 Forms: Form A and Form B, each of which has the same number of items and almost at the same level of difficulty. Each item in Form A has one parallel item in Form B, except for ITEM 1 which is appeared in both forms. The items allocated to Form A and Form B are listed in Table 1. It should be noted that in Table 1 as a more detailed illustration of Figure 1, the order of the sub-level descriptions within each level of the construct is not ranked. Each of these sub-level descriptions within one level has the same degree of importance in describing the respective level. 
Table 1. The Construct Map of the Different Levels of the Understanding of Plagiarism Construct in Descending Order of Levels and the Associated Item Numbers (\#) in Form A and Form B

\begin{tabular}{|c|c|c|c|}
\hline Level & Level Description & $\begin{array}{l}\text { Related } \\
\text { Item No. } \\
\text { in Form A }\end{array}$ & $\begin{array}{l}\text { Related } \\
\text { Item No. } \\
\text { in Form B }\end{array}$ \\
\hline $\begin{array}{l}\text { 4. Exemplary } \\
\text { understanding of } \\
\text { the concept }\end{array}$ & $\begin{array}{l}\text { 4.1. Develop and apply anti- } \\
\text { plagiarism activity }\end{array}$ & 20 & 21 \\
\hline \multirow{2}{*}{$\begin{array}{l}\text { 3. High } \\
\text { understanding of } \\
\text { the concept }\end{array}$} & $\begin{array}{l}\text { 3.2. Detect a high-level of plagiarized } \\
\text { texts }\end{array}$ & $19.1-19.2$ & $19.3-19.4$ \\
\hline & $\begin{array}{l}\text { 3.1. Identify appropriate paraphrased } \\
\text { and referenced texts }\end{array}$ & 18 & 17 \\
\hline \multirow{3}{*}{$\begin{array}{l}\text { 2. Satisfactory } \\
\text { understanding of } \\
\text { the concept }\end{array}$} & $\begin{array}{l}\text { 2.3. Know about the definition of } \\
\text { paraphrasing and referencing }\end{array}$ & 11 & 16 \\
\hline & $\begin{array}{l}\text { 2.2. Know that it violates } \\
\text { internationally-accepted academic } \\
\text { integrity and culture }\end{array}$ & 9 & 5 \\
\hline & $\begin{array}{l}\text { 2.1. Identify some plagiarism } \\
\text { practices }\end{array}$ & $10.1-10.7$ & $10.8-10.14$ \\
\hline $\begin{array}{l}\text { 1. Low } \\
\text { understanding of } \\
\text { the concept }\end{array}$ & $\begin{array}{l}\text { 1.2. Describe } 1 \text { plagiarism activity } \\
\text { 1.1. Define plagiarism }\end{array}$ & $2,3,4$ & $6,7,8$ \\
\hline $\begin{array}{l}\text { 0. No awareness } \\
\text { of the concept }\end{array}$ & Does not know what plagiarism is & 1 & 1 \\
\hline
\end{tabular}

The UPS was administered in English in order to minimize the possibility of language bias. Besides, the target respondents were all lecturers with sufficient English skill as they lectured and operated in English in IUP. After the first draft of the survey items were presented in front of the Item Panel group, the instrument was then passed on to two potential respondents in Indonesia who did a "Think Aloud" process in trying to do and examine the survey. Apart from indicating some minor grammatical errors, both suggested to reduce the number of items in order for the instrument could be done in the 30-minutes time-frame and that the survey should be done in paper-and-pencil form. Considering comments from the Item Panel group, and the Think-Aloud process as well as accommodating the Alternate-Form reliability check, the UPS items have undergone a number of revisions to better achieve the study objective and ease the data collection. An indication that the number of items might be overwhelming was discounted by hoping to get the respondents' thoughtful consideration that the UPS instrument was still in the developmental stage so that a large number of items were required. This special message was also written in the introductory part of the UPS, and personally conveyed to the respondents when the instrument was distributed. The instrument was distributed to the respondents by the assistance of several lecturers with a convenience sampling, which might incur a potential bias. The complete list of the UPS is provided in the Appendix A. The rationale of each survey item and its corresponding coding/scoring system is discussed in the following:

ITEM 1. Knowledge of the terminology.

Designed for the lowest level of the construct, this item is provided to first ask whether the respondent has heard the term "Plagiarism" before. This notion might not be recognized by one who has never studied abroad and/or is aware of the term. It is scored dichotomously, i.e. either 1 if Yes or 0 otherwise. 
ITEM 2. Difference between plagiarism and cheating.

This item ensures whether the respondent really knows whether plagiarism is actually different from cheating, in which the latter is a more common concept in Indonesian community. This item is repeated in ITEM 6 and designated to describe the "low" level of the construct. Each item is scored dichotomously, i.e. either 1 if Yes or 0 otherwise.

ITEM 3. Giving 1 example of a plagiarism practice

Referring to the "low" level of understanding, this item checks whether the respondent can give an example of a plagiarism activity, and so does ITEM 7 for a non-plagiarism activity. Each item is scored dichotomously, i.e. 1 for a correct answer, or 0 otherwise.

ITEM 4. Formal definition of plagiarism

Together with ITEM 8 to express the "low" level of understanding, this item assesses the respondent's knowledge on the formal definition of plagiarism. Each item is scored dichotomously, i.e. 1 for a correct answer, or 0 otherwise.

ITEM 5. Plagiarism as a violation of academic integration

Still on the "low" level of understanding, this item tries to assess whether the respondent accepts that plagiarism is a violation of academic integrity and it's a world-wide accepted concept. ITEM 9 is also designated for this purpose. Each item will be scored in a polytomous manner, i.e. 0,1 , and 2, having a 2 for the most correct answer.

ITEM 10. Identification of plagiarism activities

Tapping into a higher level of construct, i.e. a "satisfactory" level, this item lists examples of plagiarism activities, and is scored as 1 for a correct answer or 0 otherwise. Form A and Form B will have the same number of example items. Each Form has 7 sub-items for ITEM 10. The items were modified after academic misconduct-related activities defined by Binus International (2010), the Indonesian National Ministry Decree (Kemendiknas, 2010), and by Wilkinson (2009).

ITEM 11. Definition of paraphrasing

In order to understand plagiarism, one must also know the notion of paraphrasing which is a crucial principle in avoiding plagiarism practice. This item is repeated in ITEM 16, both of which are designed to refer to the "satisfactory" level of understanding. Each item will be scored in polytomous manner, i.e. 0,1 , and 2 , having a 2 for the most correct answer.

ITEM 12-ITEM 15. Ability to paraphrase in Indonesian and English

These items are provided for background information only, since a respondent with high level of understanding of the concept of plagiarism is expected to know about paraphrasing in both Indonesian and English. From personal communication with colleagues who obtained their first or second degree in Indonesian local universities, not many of them were taught to perform academic writing in Indonesian when they did their compulsory dissertations. When someone knows how to paraphrase in one language, performing paraphrasing in another language should not be very difficult since the principles would be more or less similar. Each item is coded dichotomously, i.e. 1 for Yes, or 0 otherwise.

ITEM 17-ITEM 18. Identification of appropriate paraphrased and referenced text

These two scenario-type items assess the "high" level of understanding by testing whether the respondent can identify the most appropriate paraphrased and referenced text from the given excerpts. The excerpts are taken from the online plagiarism exercises developed by the School of Education of Indiana University at Bloomington (School of Education, 2005). It is scored in a polytomous manner, i.e. $0,1,2$ and 3 , having a 3 for the most correct answer. 
ITEM 19. Detection of plagiarized texts

Still tapping at the "high" level of understanding, this item gives four examples (two for each Form) in which from a given original text, the respondent must identify whether the student version of written text constitutes plagiarism and give reason for the answer. The sample texts are also obtained from the online plagiarism exercises developed by the School of Education of Indiana University at Bloomington (School of Education, 2005). For the dichotomous item responding whether or not plagiarism occurs, it is scored 1 for the correct answer or 0 otherwise. A polytomous scoring system of 0,1 , and 2 with 2 for the most correct response, is used to describe reasons of why plagiarism does/does not occur in ITEM 19.2 and ITEM 19.4. Meanwhile, giving a correct reason for ITEM 19.1 and ITEM 19.3 is scored 1 or 0 otherwise.

ITEM 20-ITEM 21. Implementation of anti-plagiarism principles

These scenario-type items check the highest level of construct, i.e. "exemplary" level, to examine what the respondent would do if he/she detected a plagiarism practice. Each item is scored in polytomous manner, i.e. 0, 1, 2 and 3, having a 3 for the most correct answer. A qualitative open-ended format of this item can be found in ITEM 29.

ITEM 22-ITEM 24. Definition of the concepts

These open-ended items are provided for background information to reconfirm whether the respondent comprehends what they have responded in the survey on the definitions of plagiarism, paraphrasing and referencing.

ITEM 25. Formal referencing style

This item is presented for background information only to check whether the respondent knows what the formal referencing style that his/her current institution is having. When a solid answer is given, it might show a comprehension of one example of the anti-plagiarism principles.

\section{ITEM 26-ITEM 27. Plagiarism Workshops}

These items are provided for background information only to see how many respondents have ever attended a workshop on plagiarism. Should not many respondents ever attend such workshop and the outcome of this survey shows an insufficient understanding of plagiarism, then a future profession development on this issue could be strongly recommended.

ITEM 28-ITEM 29. Detection of past plagiarism practices

These two items are provided for background information only to see whether the respondent has ever detected any student plagiarism practice, which should often happen in Indonesia.

ITEM 30-ITEM 31. Understanding of campus policy on plagiarism

These two items are provided for background information only to see whether the respondent has a comprehension of the campus policy on plagiarism, which also includes the use of plagiarism detection software. Each item is coded dichotomously, i.e. 1 for Yes and 0 otherwise.

A series of background information about the respondents was also administered to investigate whether this information have any association with the level of understanding of the concept. It included gender, age, education background details, teaching experience, perceived self-competency on English skill, preference of language of the future survey, and time taken in filling in the survey. These items are coded dichotomously or polytomously, depending upon the nature of each item.

For selected respondents, a set of Exit Survey items was developed and administered to ask for their comments and suggestions for a further development of the survey. It included questions on which survey items were found to be easy or difficult, and whether it could assist the respondent to get a more understanding of the concept of plagiarism. 


\section{Statistical Model Used}

In this study, the Master's partial credit model (Masters, 1982) - a member of Rasch family model (Rasch, 1960), was used to estimate the understanding of plagiarism scores among the respondents. With this modelling approach, a mixture of dichotomous and polytomous items can be scored and the given score estimates can explain how the lecturers' level of understanding of plagiarism along the hypothesized construct. Each respondent $p$ 's latent understanding of plagiarism is estimated using a probability model where the probability $\left(P_{i k}\right)$ of answering an item $i$ in response category $k$ is a function of the difference between the location of person $p$ and the location of item $i$. The PCM can be formulated as

$$
\eta_{p i}=\theta_{p}-\left(\delta_{i}+\tau_{i k}\right)
$$

Here, $\eta_{p i}=\log \left(\frac{P_{i k}}{P_{i k-1}}\right)$ is the logit link to represent the probability model as a linear function of person latent ability $\theta$ on each dimension $d$, the relative item difficulty $\delta_{i}$ for a particular item $i$ along with its kth threshold parameter $\left(\tau_{i k}\right)$ when using PCM. The threshold parameter $\left(\tau_{i k}\right)$ is the deviation from the mean item difficulty $\delta_{i}$ for item $i$ at step k (i.e. $\left.k=0, \ldots, K\right)$ and constrained such that $\sum_{k=0}^{K} \tau_{i k}=0$. The parameter estimation software ConQuest was used for estimating the parameters ( $\mathrm{Wu}$, Adams, Wilson, \& Haldane, 2007).

\section{Results and Discussion}

\section{Participant Characteristics}

The number of respondents participating in this survey is 32 lecturers $(n=32)$. To better understand the survey results, some important background information of the respondents are presented in the following. There are 18 female and 14 male respondents, and more than $60 \%$ of them working full-time at their current institution with more than 6 years of teaching experience. This was expected since most respondents were graduated from overseas universities with scholarships, and some of which are currently taking graduate programs in Australia, UK and US, also under various scholarships. In Indonesia, having a full-time teaching status at a higher education institution and some teaching experience became favorable factors in getting a scholarship to do a graduate study. The respondents' perceived self-confidence in their English competency skills as shown in Error! Reference source not found.(a) and (b) are also not surprising. Result from the related-items about English skills (ITEM 5.1 and 5.2 in Part B) indicates that more than half of the respondents felt highly confident in their English reading and comprehension skills as they had no difficulty whatsoever in reading English textbooks and academic journal within their intellectual capacity. Similarly, they have high confidence on academic writing because most of them had written academic publications in English. Some even claims to have more than 3 academic publications including internationally-ranked journals. Hence, language would not be an issue for the current sample. However, this could give a high conjecture that most of these respondents would have already been comprehensible of the concept of plagiarism. In addition, there is slightly more respondents (56\%) who have ever attended a plagiarism-related workshop than those who have not (44\%).

The calibration of the survey data was performed several times using ConstructMap ${ }^{\circledR}$ to see whether all item fit categories were available and fit within allowable standards (Wilson, 2005). A frequency analysis was also performed to check for any missing data. Here, ITEM 20 appeared to be problematic since there was no response for category 0 , while its parallel item, ITEM 21, had all of its categories responded. This called for another rescoring process to collapse Category 0 and 1 into "0", whilst Category 2 became a " 1 " and the most correct response, Category 3, became a " 2 " as illustrated in Table 2. Furthermore, ITEM 5 had also no response for Category 0 , and thus this particular item and its parallel 
item (ITEM 9) had to be excluded from the final data set. Appendix B lists the final items used for the final analysis along with the scoring system.

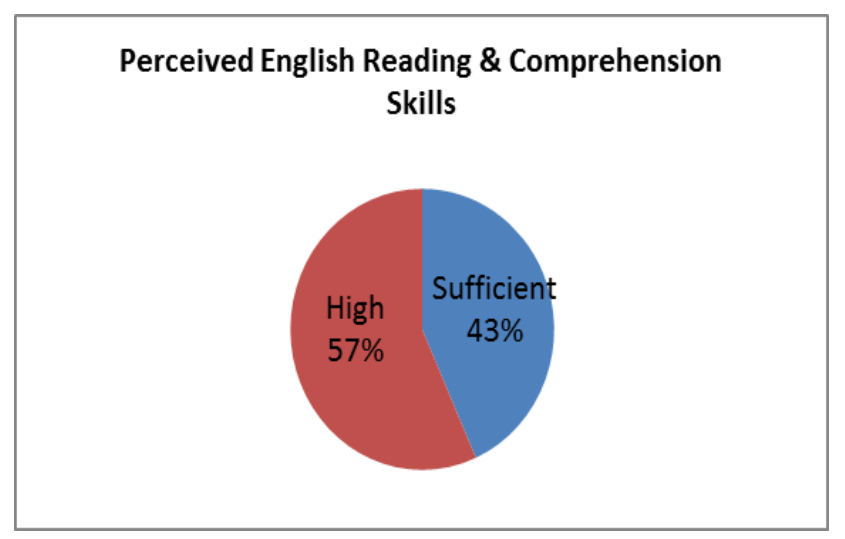

(a)

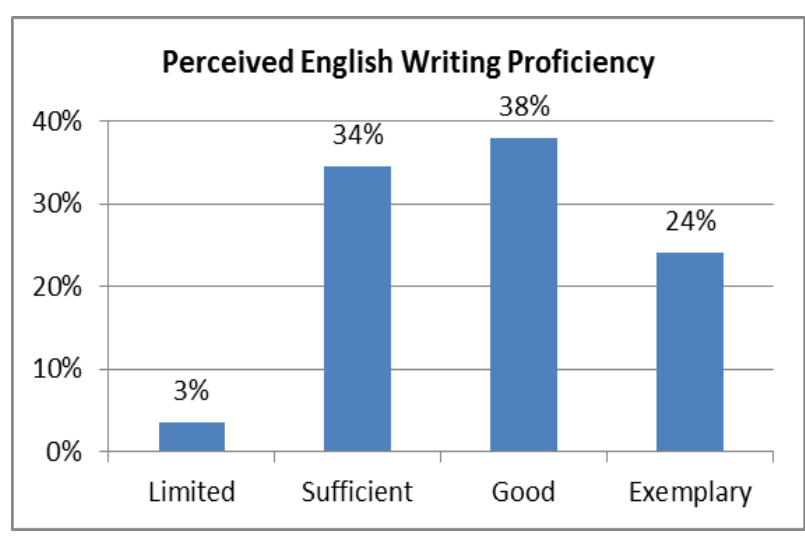

(b)

Figure 2. The Respondent's Perceived Self-Confidence on The English Competency in (A) Reading and Comprehension, and (B) Writing Skills.

Table 2. Response Counts for Each Category of ITEM 20 and ITEM 21 before and after Rescoring Process

\begin{tabular}{crrrr}
\hline \multirow{2}{*}{ Category } & \multicolumn{2}{c}{ Before Rescoring } & \multicolumn{2}{c}{ After Rescoring } \\
\cline { 2 - 5 } & Item 20 & Item 21 & Item 20 & Item 21 \\
\hline 0 & 0 & 1 & 9 & 12 \\
1 & 9 & 11 & 8 & 6 \\
2 & 8 & 6 & 15 & 14 \\
3 & 15 & 14 & & \\
\hline
\end{tabular}

The final data set with 26 items was then input to ConstructMap ${ }^{\circledR}$ and calibrated to give a better estimation of UP levels. Error! Reference source not found. presents the Wright Map of the final data set. The items were clustered between -3.0 logits and +2.0 logits, whilst the respondents were closely located within 2.0 logits. As predicted, the respondent locations were estimated rather higher than the item locations as most of the items were clustered in the lower end. Having a maximum score of 30, the mean UP level estimate was given as 1.4455 with a standard error of measurement (SEM) of 0.437 (raw score of 22), while the average of item difficulty estimate was 0.275 with an average SEM of 0.211 . The overall S.E of the mean was 0.0983 . The maximum raw score in this data set was 26 , and the minimum was 15. In this figure, it was apparent that a respondent with an average UP level would have less than $50 \%$ probability to answer ITEM 19.2.2, 19.3.2, 19.4.2, and 20 correctly, but would be more likely to answer the rests easier. For ITEM 19.4.2 which had more than 1 threshold corresponding to the completeness of reasons given to why such a plagiarism occurred in a student's text, it seemed that not many respondents gave a complete answer or even gave any answer to this item causing the item to have the highest item difficulty or location. The magnitude of the SEMs was also considered acceptable as shown in Error! Reference source not found. It demonstrates that the respondent's UP levels were estimated higher than the item difficulties and that the most sensitive part of the instrument was around the mean UP level estimate of +1.4 logits where most items were clustered. 
JP3I (Jurnal Pengukuran Psikologi dan Pendidikan Indonesia), 9(2), 2020

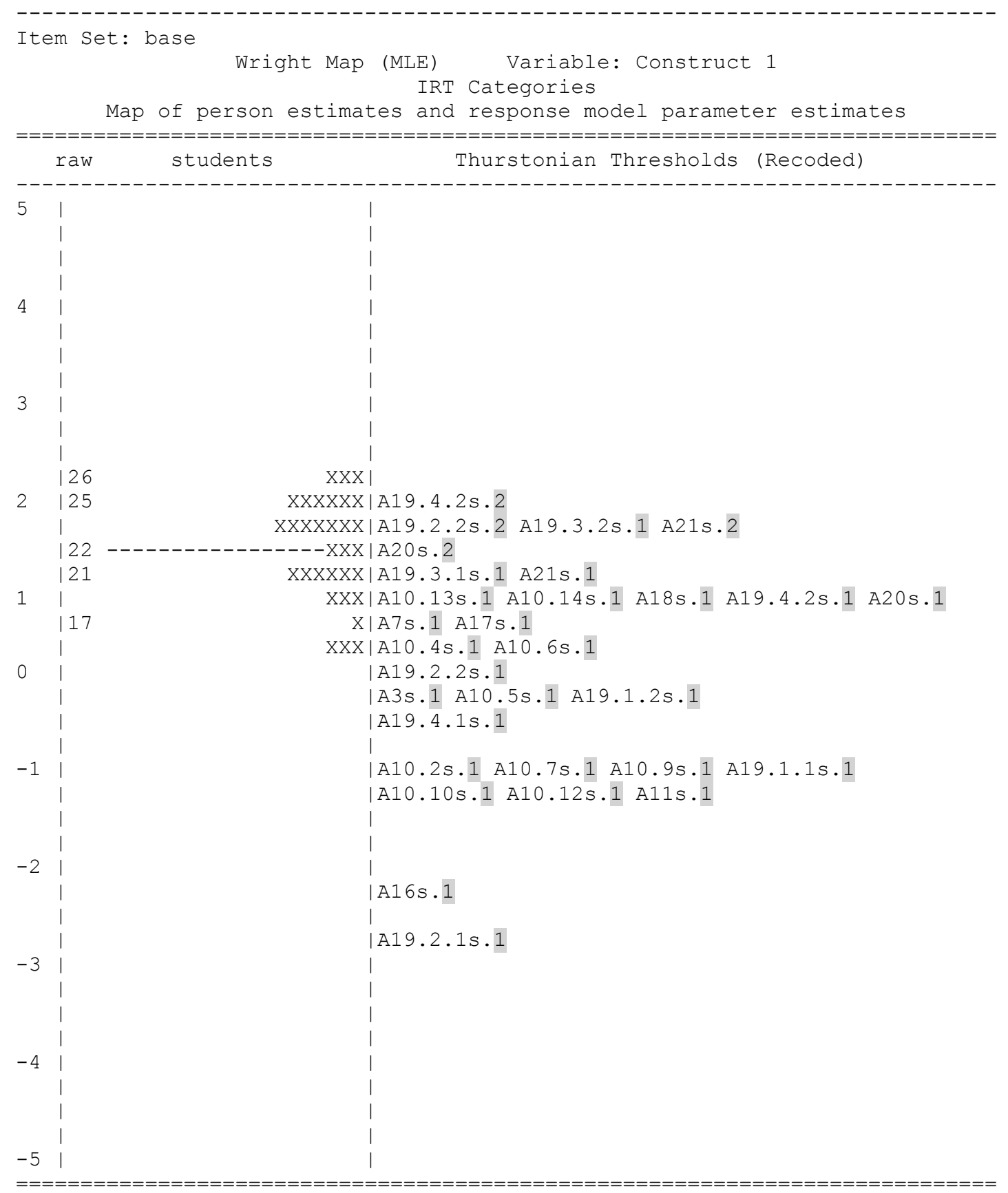

Each $\mathrm{X}$ represents 1 student, each row is 0.255 logits

Figure 3. A Wright Map for the UPS Instrument Consisting of 26 Items. The Shaded Number Represents the Thresholds of the Particular Item 


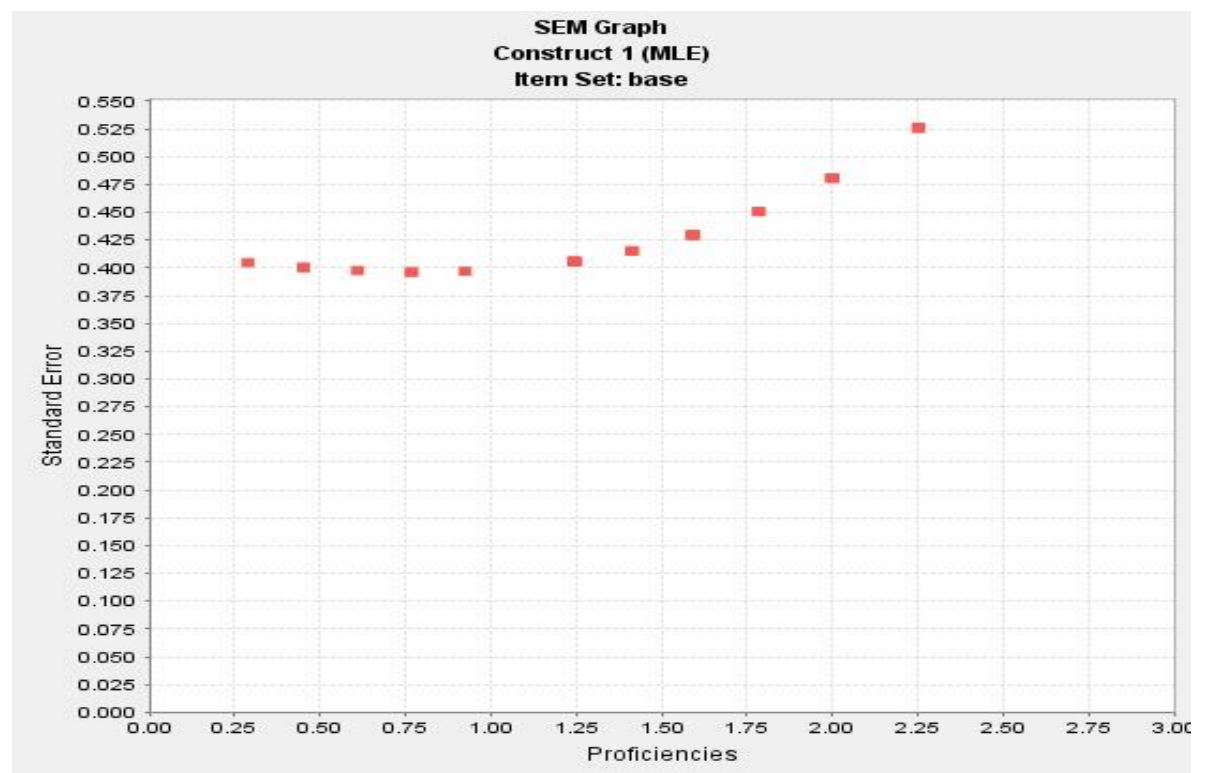

Figure 4. A SEM Graph of The UPS Instrument with Final Data Set

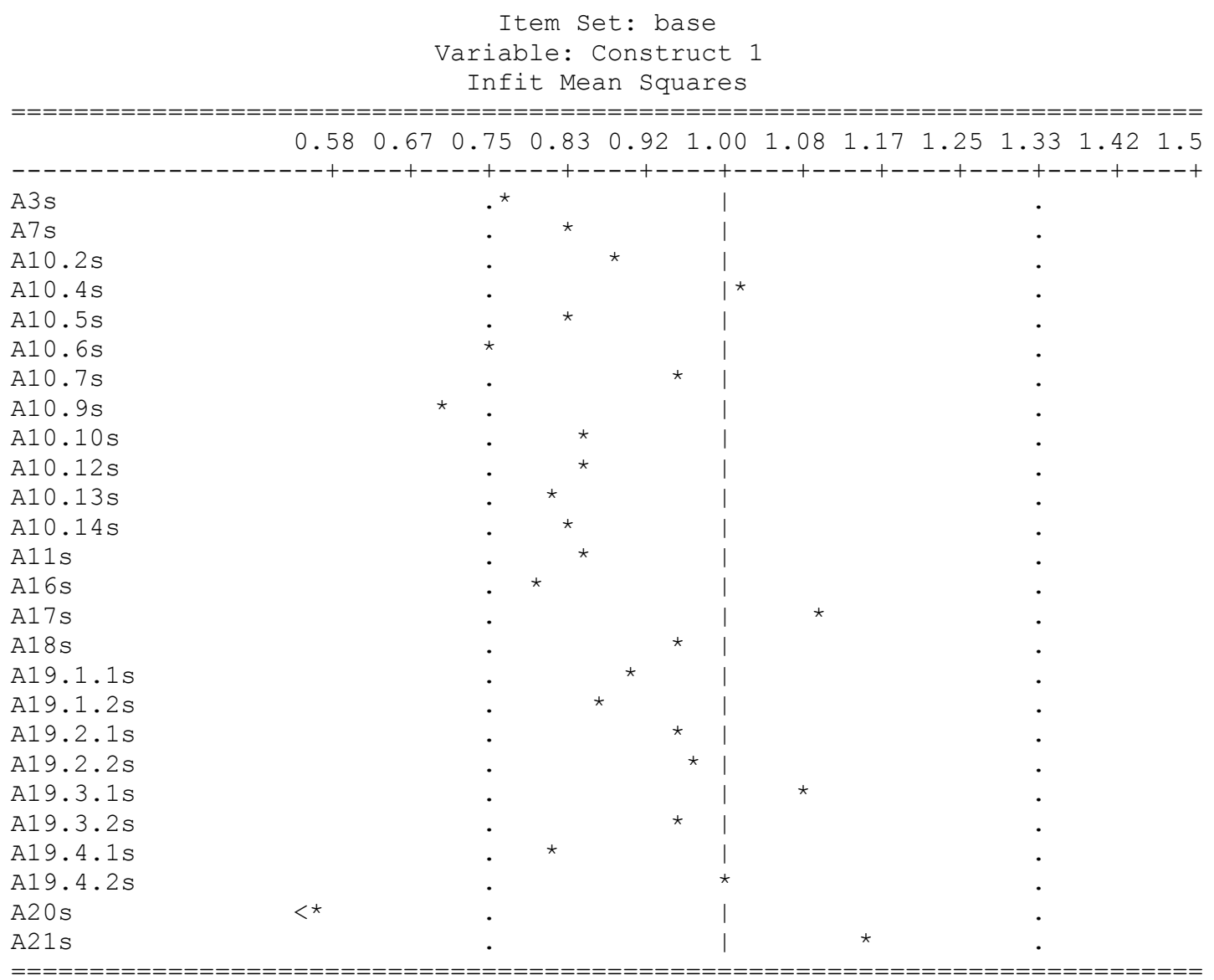

Figure 5. Item Fit Report for the UPS Instrument 


\section{Item and People Fit Analysis}

Error! Reference source not found. illustrates the item fit graph indicating that no overly-random items had occurred. Most items were located within the allowable bounds of the in fit or weighted meansquares, i.e. 0.75 - 1.33 (Adams \& Khoo, 1996 as cited in Wilson, 2005), except for ITEM 10.9 and ITEM 20 being on the left quadrant of the lower bound. After examining the corresponding item analysis report, the misfit of ITEM 10.9 was insignificant ( $t$-statistics $=-1.3$ ), but ITEM 20 seemed to be significantly over fit by having a t-statistics of -3. 44, as illustrated in its Item Report in Error! Reference source not found. Again, it might be due to the small sample size because the mean location estimates did increase as the score increased for this particular item. Meanwhile, examining the person fit graph as given in Error! Reference source not found.(a) indicates that some apparent person misfits as some respondents' weighted mean squares (in fit) were outside the allowable bounds as described above. However, none of them was considered significant as confirmed by having no corresponding t-statistics located outside the allowable bounds (see Figure $7[b]$ ).

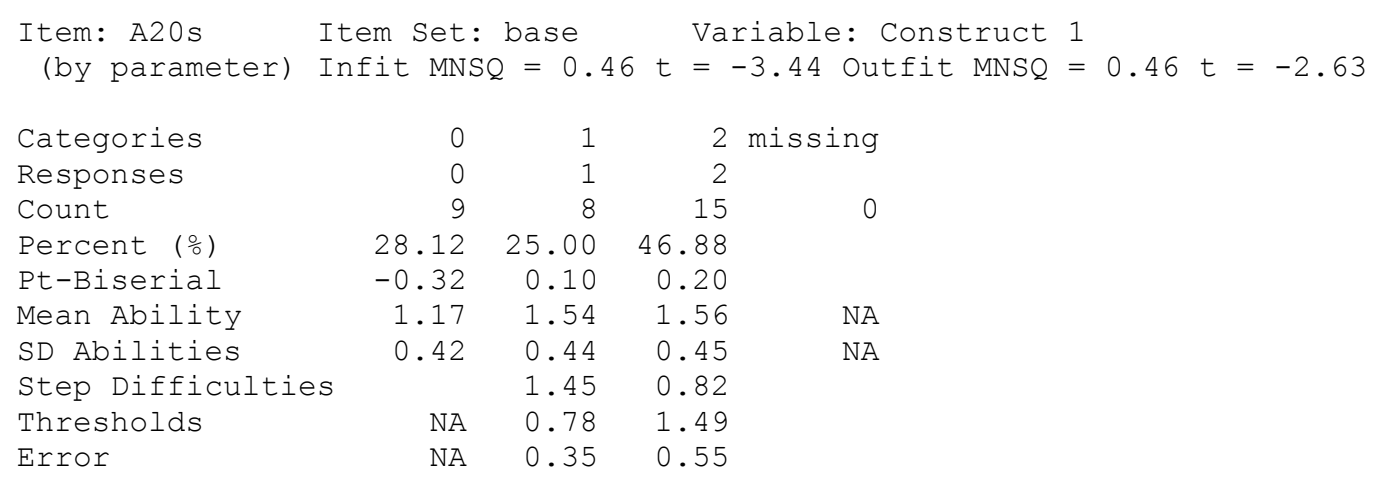

Figure 6. Item Report for ITEM 20 of the UPS Instrument Using Final Data Set

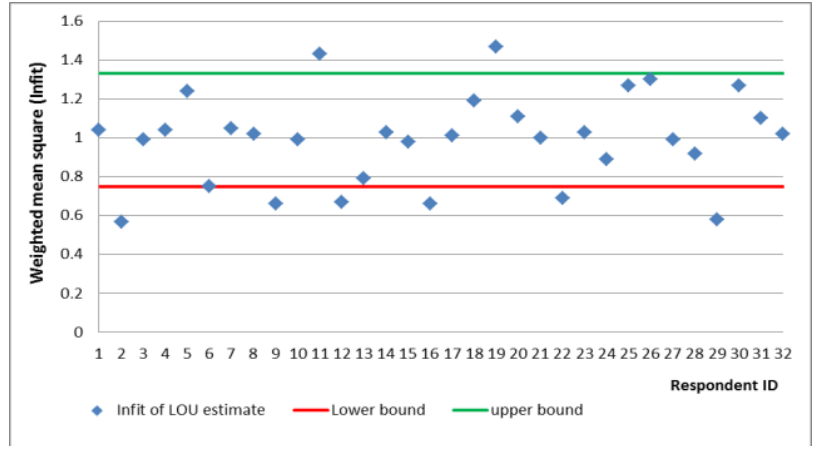

(a)

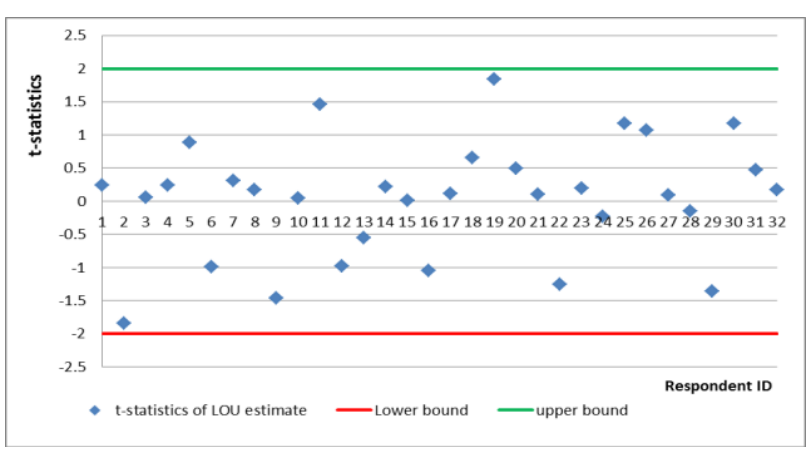

(b)

Figure 7. Person Fit Report for The UPS Instrument Using (A) Weighted Mean Square (Infit) And (B) T-Statistics

To illustrate some respondents' response patterns, As described above, the limited number of samples in the dataset might have caused low reliability of the UPS. In addition, the nature of items used in this survey was very diverse in terms of format and required responses, which might also influence the reliability of the survey. Better item development is warranted to ensure the conformity and uniformity of the items.

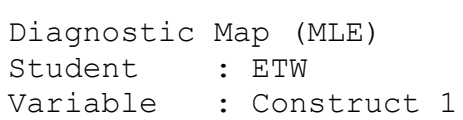




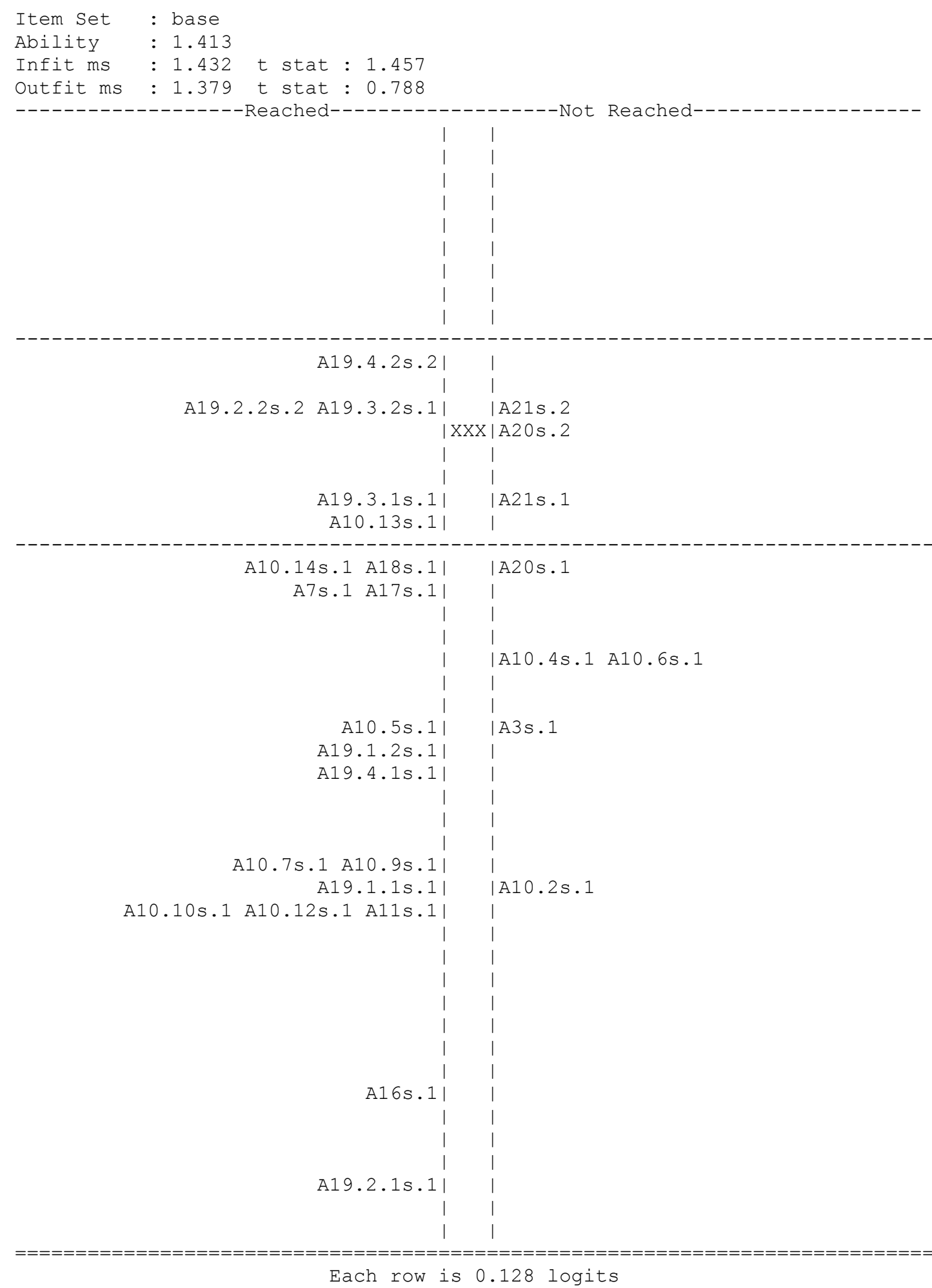

Figure 8 and Error! Reference source not found. present the kidmaps of two respondents, coded as ETW and RR, respectively. ETW had a mean UP level estimates of 1.413 and a raw score of 22, showing some randomness by having a slightly-insignificant infit of 1.432 . There was an apparent set of items in the lower right quadrant of the kidmap, indicating some near-randomness. Next, the near-randomness of $\mathrm{RR}$ (infit $=1.47$, t-statistics $=1.84$ ) was shown by having some sets of items appeared in the upper left and lower right quadrants of the kidmap. 


\section{Reliability}

As previously explained in the preliminary instrument calibration section, the consistency of the UPS instrument in estimating the level of understanding of the plagiarism concept was measured by the following reliability coefficients:

- Internal consistency coefficient

Using the final data set, this instrument gave a lower Cronbach's alpha of 0.41 , which might be due to the low variability of responses. Similarly, a better representative sample would be required to improve this reliability coefficient.

- Person separating reliability score

The person separating reliability score for this instrument was also lower, i.e. 0.37 suggesting a low ability of the UPS instrument to discriminate the respondents' level of understanding.

- Alternate Form reliability

When the two sets of forms: Form A and B were correlated, the alternate forms reliability coefficient was given by 0.245 . Similarly, the low variability of responses might have caused the low reliability scores.

As described above, the limited number of samples in the dataset might have caused low reliability of the UPS. In addition, the nature of items used in this survey was very diverse in terms of format and required responses, which might also influence the reliability of the survey. Better item development is warranted to ensure the conformity and uniformity of the items.

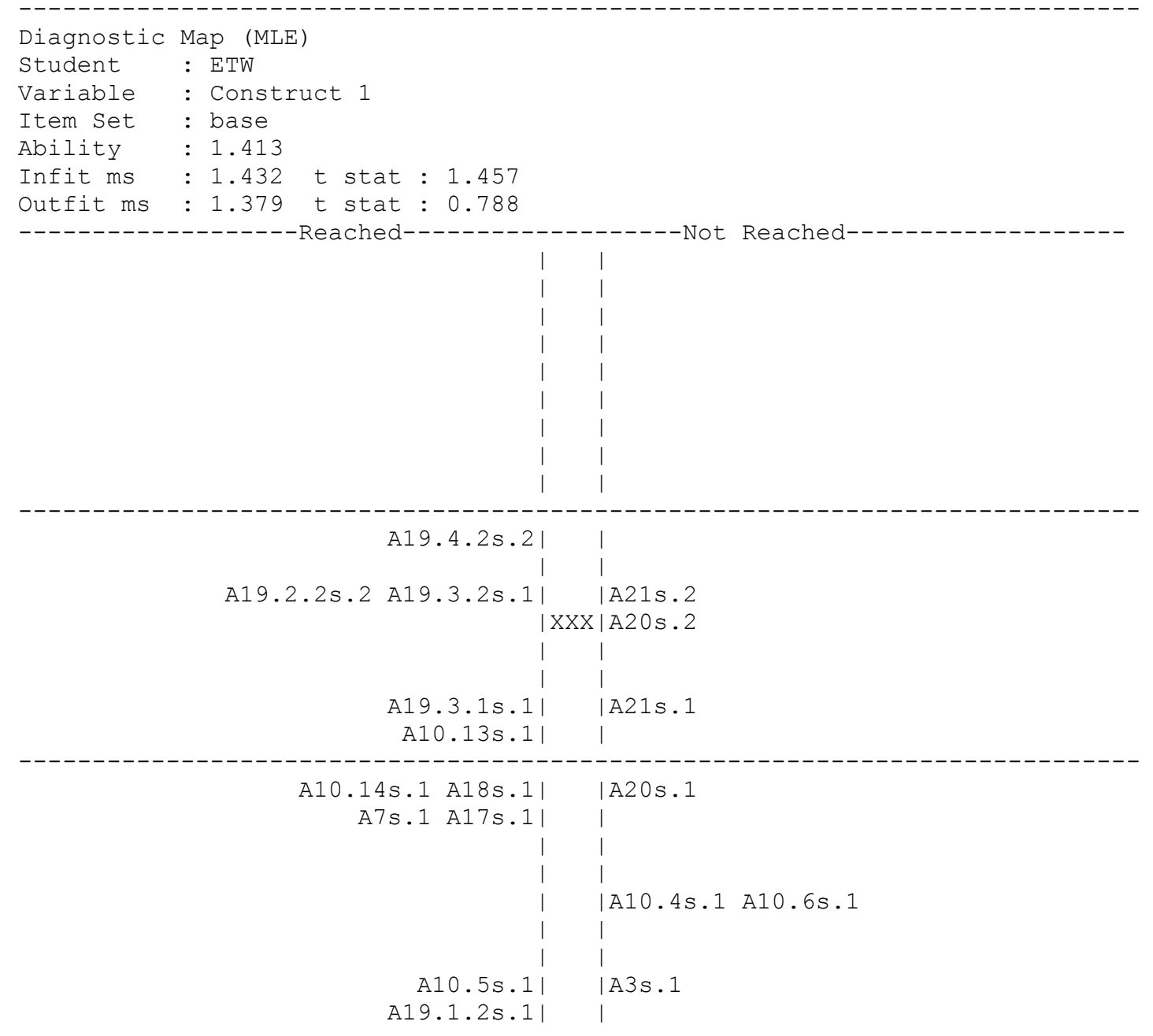




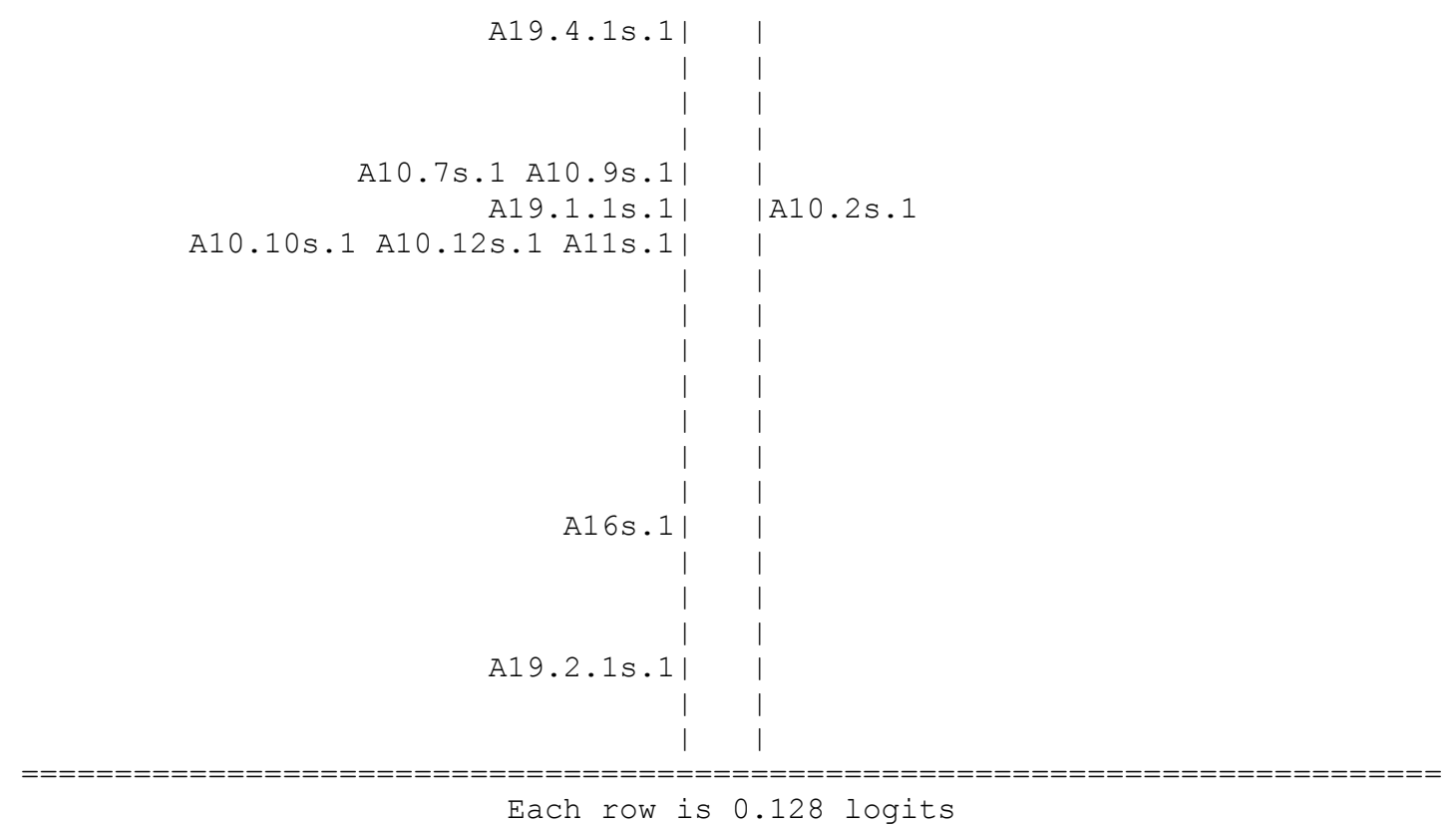

Figure 8. A Kidmap for ETW's Response Patterns to the UPS Instrument

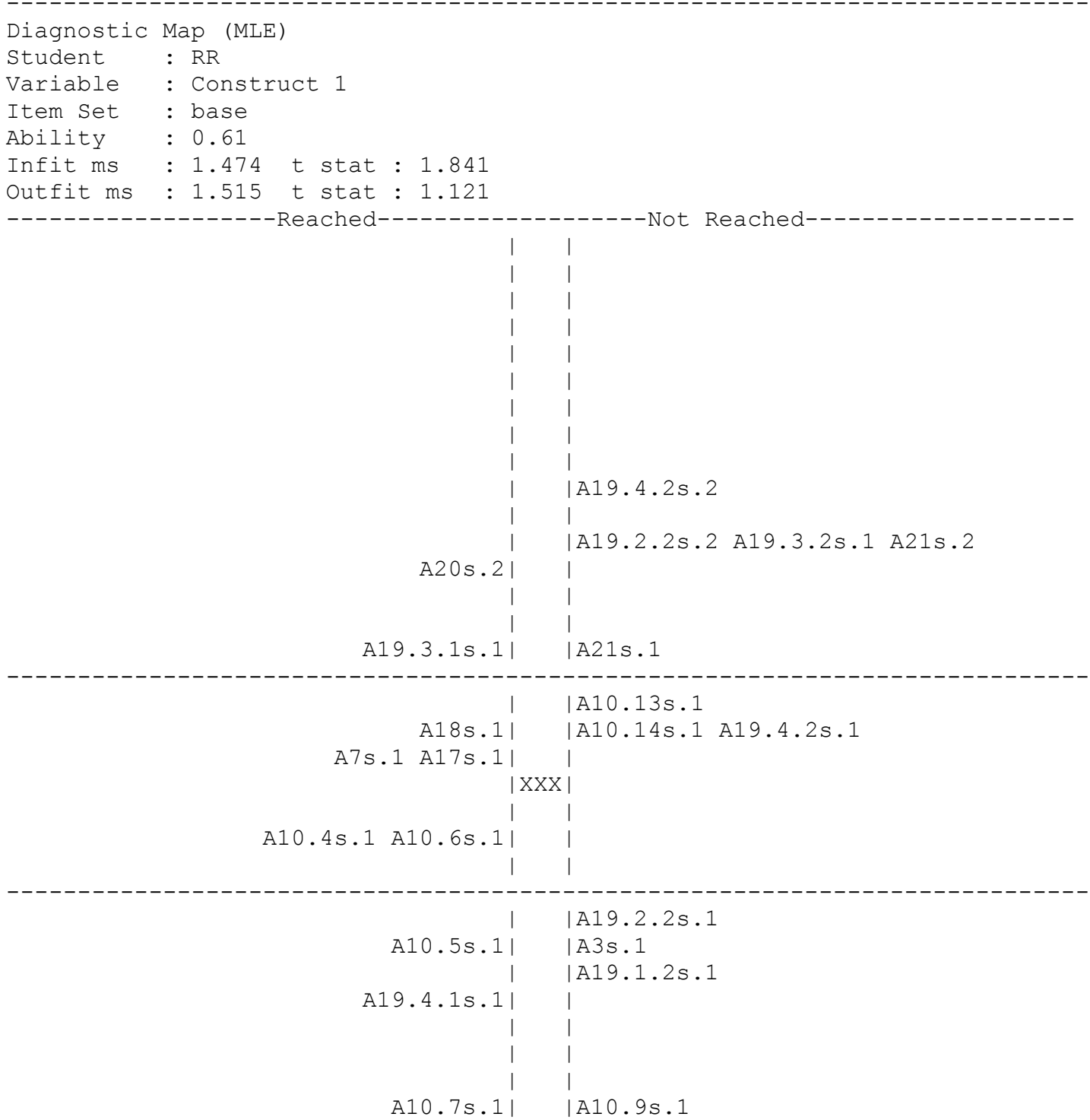




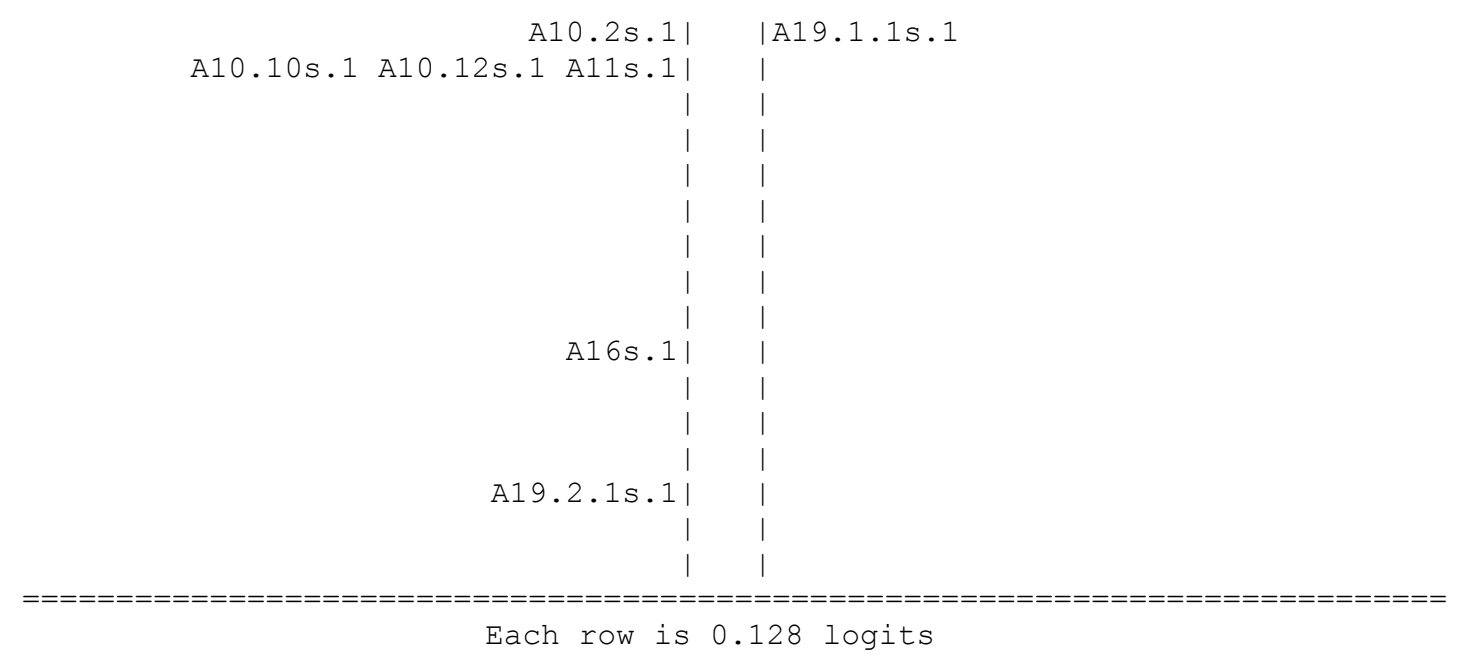

Figure 9. A Kidmap for RR's Response Patterns to the UPS Instrument

\section{Validity}

Drawn from the standards of validity evidence developed by the AERA, APA, and NCME (2014), this study now aims to justify whether the UPS instrument can really measure what it has claimed to measure by presenting the following discussion on the five strands of validity evidence.

- Evidence based on instrument content

Rigorous steps have been taken in the development of the construct and its measurement tool or instrument, as thoroughly documented in earlier sections. This documentation could be considered as a thorough representation of the content validity evidence for the UPS instrument. Results from the survey and exit interview presented that the instrument could measure the understanding of plagiarism (UP) levels among Indonesian lecturers, although did not represent the proposed levels of construct delineated in the Introduction section.

- Evidence based on response processes

In administering this study, two activities of engaging the respondents in the analysis of responses have been conducted by performing "Think Aloud" and "Exit Interview'. The "Think Aloud" process was performed by chatting with two potential respondents at BI via Yahoo Messenger who read through the UPS instrument and gave written comments. For the Exit Interview process, selected respondents did additional items included in the UPS to give comments on the overall survey items. A chat-interview was also conducted with 1 respondent after she did the survey. Both processes yielded similar outcomes suggesting that the scenario-based items seemed to be the hardest and that the number of items was overwhelming.

- Evidence based on internal structure

a) Instrument Level

Although the items were not well spread throughout the continuum of the UP level estimates in the current group of respondents, it can be seen from the Wright Map in Error! Reference source not found. that the item difficulty estimates of ITEM 19, 20 and 21 were higher than the rest of items. ITEM 17, ITEM 18 and some of ITEM 10 were one degree less, and then followed by ITEM 3 and 7. This order has somewhat agreed with the proposed item locations in the construct map as presented in Error! Reference source not found.. Meanwhile, the location of ITEM 11 and 16 were apparently lower than the others. Surprisingly, the open-ended ITEM 3 and 7 appeared higher than expected. Scored dichotomously, it was noted that the respondents with high level of understanding 
of plagiarism still found it difficult when having to write examples of plagiarism or non-plagiarism practices in their own words. Several respondents, though, skipped these open-ended items making them scored zero at the end. The finding suggests that current results have not seemed to be able to describe the hypothesized UP levels. However, with such a small sample of respondents that is also not quite representative of the target population, the order of item difficulties at this stage could not be verified. Another round of survey item development and administration was needed. Should a more representative sample be obtained, a better distribution and order of item locations could be predicted.

b) Item Level

The mean location of most items tended to increase as the score increased, except for ITEM 11 as shown in Error! Reference source not found.. This might be due to the small number of respondents got a zero score in comparison with those with a score of 1 . Due to a limited sample size, no Differential Item Functioning (DIF) analysis was performed in this study.

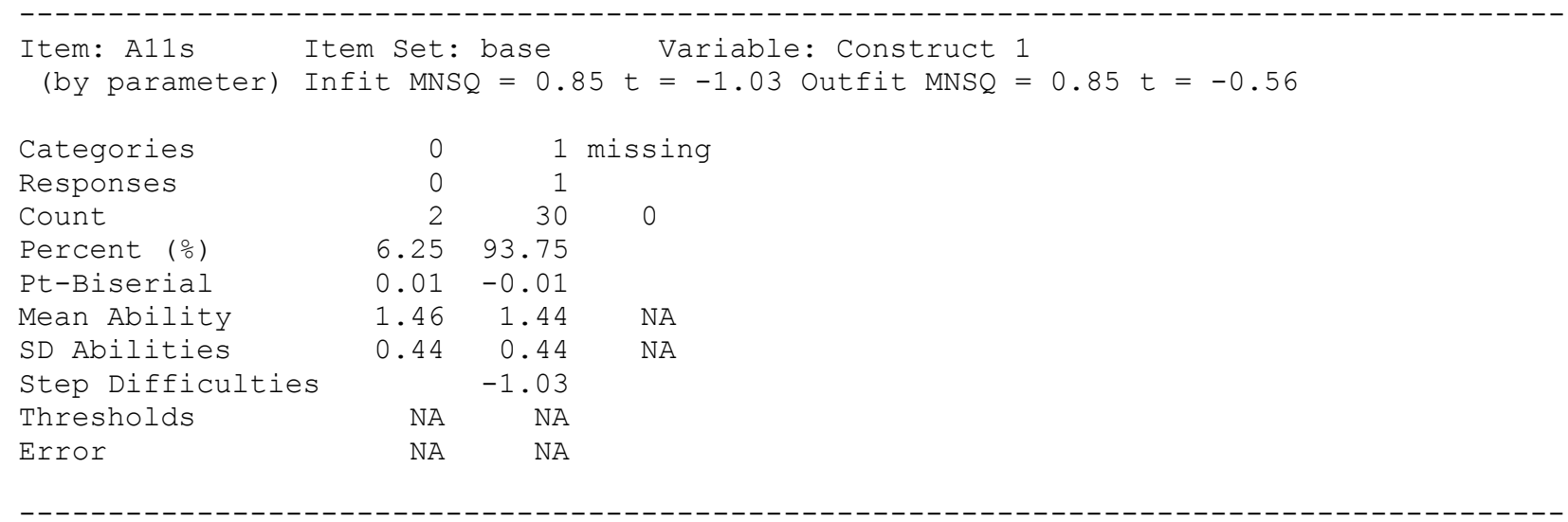

Figure 10. Item Report for ITEM 11 of the UPS Instrument

- Evidence based on relations to other variables

This study is a continuation of a past research which found that all lecturers were aware of the concept of plagiarism, but did not have a fully comprehension on the technicalities, e.g. deciding which academic misconduct constitutes plagiarism, how to detect plagiarized text, and how to perform appropriate paraphrasing and referencing technique (Adiningrum, Wihardini, \& Warganegara, 2011). The outcomes of the current study did show some agreements with the past result because it indicated that ITEM 17, 18, 19, 20, and 21 were located in the upper end of the spectrum. These items consisted of scenarios to assess the understanding of paraphrasing and referencing, and ability to detect whether a given text could constitute plagiarism. Besides, recalling from the results of the Think-Aloud and Exit Interview processes, they were also considered as the hardest items. When testing for a mean difference of the UP level estimates based on gender and the attendance of plagiarism-related workshop, no statistically significant differences were found. As expected, this might be due to the small sample size.

- Evidence based consequences of using an instrument

The good consequence of using this UPS instrument includes, but not limited to, giving informed knowledge to the program's policy-makers about the level of understanding of its faculty staff on the concept of plagiarism which would then assist them in maintaining a solid academic integrity in the school environment and designing professional development programs to promote anti-plagiarism 
principles. Nationally, this survey can be used to assist the Directorate of Higher Education to map out the distributions of levels of understanding of plagiarism of academic staff at any Indonesian higher education institutions and alert such institution to promote anti-plagiarism campaign by providing plagiarism awareness activity, should there be an indication of low understanding of the concept. However, this could also be culturally sensitive since not many faculty staff would be keen to be monitored on academic honesty. This survey might then bring a bad consequence if it is used to give sanctions to any faculty that shows a low level of understanding of plagiarism concept.

\section{Conclusion}

First of all, the analysis of the survey responses suggests that the survey items cannot span all of the different hypothesized levels of the lecturer's understanding of plagiarism construct, which might be due to the limited and unrepresentative sample of respondents. However, the analysis could suggest that there might only be two levels of the construct so that either one knows about the concept of plagiarism or does not. Therefore, the construct may just have "low" and "high" levels as illustrated by having two criteria zones of the UP level estimates in Error! Reference source not found.. For developing these zones, the cut-off score was chosen to be about +1.0 logits after intuitively observing the characteristics of the items and the distributions of the UP level estimates. With this zoning system, the hardest items, i.e. ITEM 19, 20, 21 still appeared in the "High" zone. Surprisingly, ITEM 3 and 7, which were supposed to be measuring the low level of understanding, were found to be rather difficult for most respondents and skipped by some since they had to give examples of plagiarism and non-plagiarism practices in writing. In ITEM 22, 23, and 24 where respondents confirmed their understanding of the definition of plagiarism, paraphrasing, and referencing by writing them down on open-ended items, it was also found that most of them responded incompletely. Unfortunately, these items were excluded in the current analysis since there were no parallel items that could be included for the Alternate Form reliability check. For a future survey, this type of item can be included to better estimate the UP level by having them scored polytomously according to the completeness of the response. However, if the sample was more representative, the distributions of respondent and item estimates might suggest differently.

Secondly, the reliability checks did not provide promising values, either. Although the discussion of validity evidence can be presented thoroughly, the limited number of cases failed to generate the sufficient variability in the responses required for the partial credit model to produce good UP level estimates. Therefore, so long as the sample data were not representative enough, it would be difficult to make any judgment on the results of this study.

Hence, for further improvement of this UPS, the following approach should be taken:

- Redesign the construct

The proposed five levels of construct on the level of understanding of plagiarism might be too many. A solid two- or three-level construct could be more feasible and proposed later after reviewing more literature on the plagiarism concepts in regard to academic faculty in non-Western education institution. 
(a)

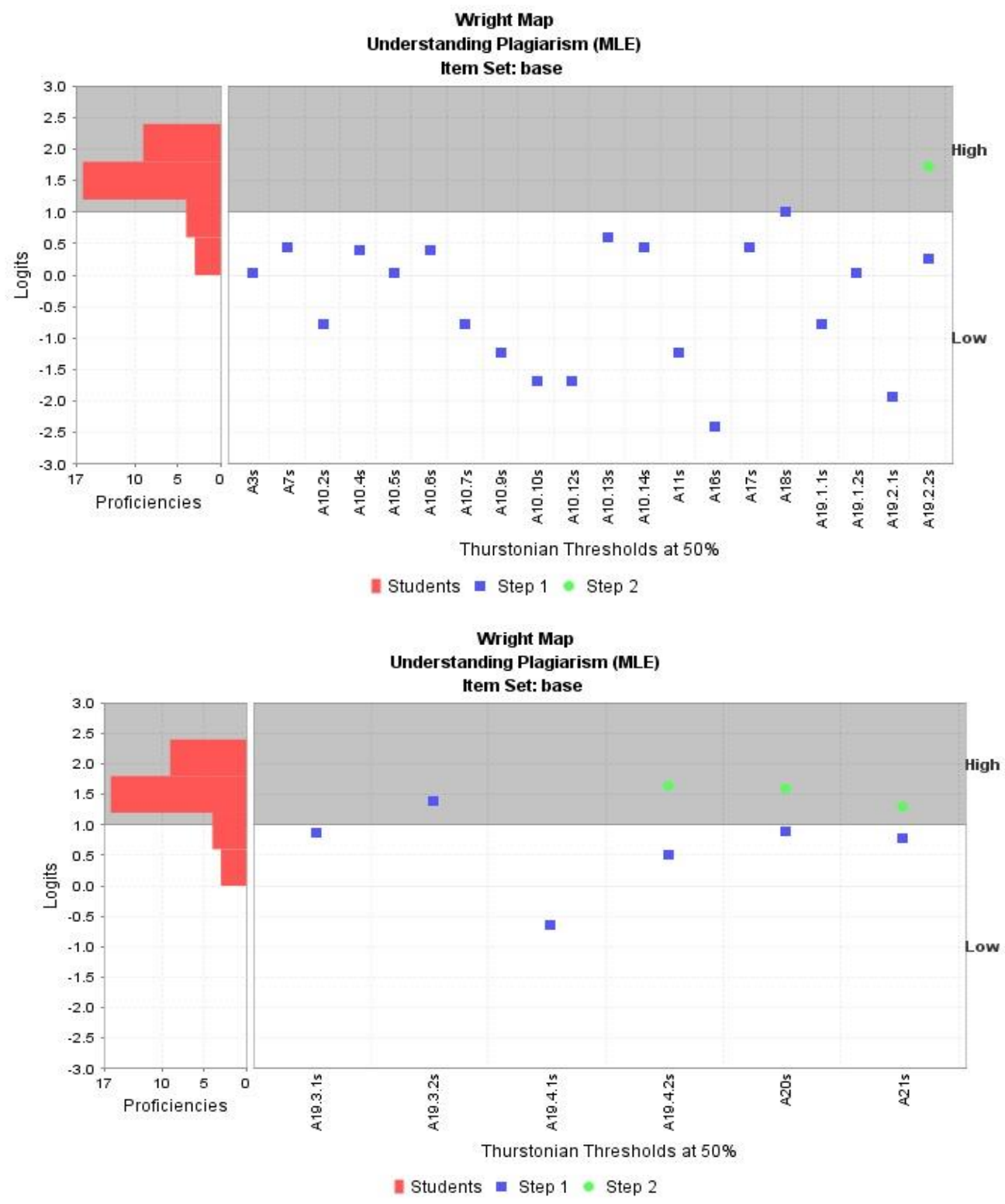

Figure 11. Criteria Zones of the Level of Understanding of Plagiarism (UP Level) Estimates for the UPS (A) Items A3s - A19.2s and (B) Items A19.3.1s - A21s

- Revise the item design and scoring

This survey can be second-piloted to include fewer items but with more scenario problems such as ITEM 17, 18 and 19 to better measure the technicalities of anti-plagiarism principles. Items, designated to measure the low level of understanding such as ITEM 4, 5, 8 and 9, should be revised and reworded. The inclusion of open-ended items that requires the respondent to write down what they know of the definition of plagiarism, paraphrasing, and referencing may contribute to the estimation model by scoring them polytomously according to the degree of correctness and completeness of the response. Should the number of levels in the UP construct be redefined, more items need to be developed to be more relevant to tap into the different levels. A simple attempt is probably to define only 2 levels of the UP construct: low and high. Thus, simple and difficult items that can differentiate responses into these two levels are to be constructed, while maintaining the conformity of the item format. 
- Provide bilingual instrument

More than half of the respondents suggested that the UPS instrument should be bilingual, while two respondents preferred it to be in Indonesian only. Indeed, language could probably an issue if the instrument was distributed nationally at a later stage. Thus, a rigorous step will need to be taken to translate the items into Indonesian in order to avoid translation effect.

- Get a more representative sample

Once the instrument has been revised and translated into Indonesian, a respondent may then be given a choice of taking the English or Indonesian version of the instrument later. If the two languages were put into the same instrument, it can be more overwhelming and annoying, especially for a respondent with either high or low command of English. A better online instrument should also be developed to ease administration and distribution of the survey.

In summary, the proposed UPS instrument cannot adequately represent the hypothesized levels of understanding of plagiarism construct as introduced in this study, due to limited number or sample and thus, variability in the responses. However, this paper has sufficiently described the necessary steps to produce a good instrument that can assess a newly defined construct like plagiarism. How each instrument item can contribute to the explanation of the construct will definitely be helpful for setting a focus on a lecturer training on plagiarism prevention and mitigation. The instrument's response patterns can pinpoint which area of understanding of plagiarism that respondents likely lack. Having obtained this information, the university authority can then design a tailored workshop for the lecturers to improve their level of understanding in such particular area. Once these lecturers have the same understanding of the concept, policies and efforts to deter plagiarism practices can be consistently enforced by the university authority, which in the long run will increase the university's academic reputation.

\section{References}

American Educational Research Association (AERA), American Psychological Association (APA), \& National Council on Measurement in Education (NCME). (2014). Standards for educational and psychological testing. Washington, DC: Authors.

Adiningrum, T. S. (2008). Understanding and managing plagiarism between East and West: A case study of Indonesian postgraduate students at Flinders University. Master's Thesis, School of Education, Flinders University, Australia.

Adiningrum, T. S., Wihardini, D., \& Warganegara, D. L. (2011). Exploring plagiarism awareness and its impact on assessment design: a case study of an Indonesian Business School. $37^{\text {th }}$ International Association of Educational Assessment Conference, Manila, The Philippines.

Akbar, R. \& Picard, M. (2019). Understanding plagiarism in Indonesia from the lens of plagiarism policy: lessons for universities. International Journal for Educational Integrity, 15(7). https://doi.org/ $10.1007 / \mathrm{s} 49079-019-0044-2$

Alvin Sherman Library. (2009). Citing Sources Using APA Manual (6th ed.). Retrieved from www.nova.edu/library/dils/teachinghandouts/apa/APA_6th_ed.pdf

De Boeck, P. \& Wilson, M. (2004). Explanatory Item Response Models: A Generalized Linear and Nonlinear Approach. New York: Springer-Verlag.

Kemendiknas. (2010). Pencegahan dan penanggulangan plagiat di perguruan tinggi (Deterring and overcoming plagiarism in higher education institution). Permendiknas No. 17 2010. Jakarta: Ministry of National Education of the Republic of Indonesia 
Kusumadara, A. (2008, April 10-12). Problem of enforcing intellectual property laws in Indonesia. Paper presented at the Law of International Business Transactions: A Global Perspective Conference, Hamburg, Germany.

MacDonald, R. \& Carroll, J. (2006). Plagiarism - a complex issue requiring a holistic institutional approach. Assessment \& Evaluation in Higher Education, 31(2), 233-245.

Masters, G. N. (1982). A Rasch model for partial credit scoring. Psychometrika, 47, 49-174.

Rasch, G. (1960). Probabilistic Models for Some Intelligence and Attainment Tests. Copenhagen, Denmark: Danish Institute for Educational Research.

Robinson-Zanartu, C., Pena, E. D., Cook-Morales, V., Pena, A. M., Afshani, R., \& Nguyen, L. (2005). Academic crime and punishment: faculty members' perceptions of and responses to plagiarism. School Psychology Quarterly, 20(3), 318-337.

Sardjono, A. (2006). Hak kekayaan intelektual dan pengetahuan tradisional (Intellectual property right and traditional knowledge). Bandung: PT. Alumni

Whitley, B.E. \& Keith-Spiegel, P. (2001). Academic integrity as an institutional issue. Ethics and Behavior, 11(3), 325-342.

Wilkinson, J. (2009). Staff and student perceptions of plagiarism and cheating. International Journal of Teaching and Learning in Higher Education, 20(2), 98-105.

Wilson, M. (2005). Constructing measures: An item response modeling approach. Mahwah, NJ: Lawrence Erlbaum Associates, Inc.

Wu, M.L., Adams, R. J., Wilson, M. R., \& Haldane, S. A. (2007). ACER ConQuest version 2.0: Generalised item response modelling software [Computer software and manual]. Camberwell, Victoria, Australia: ACER Press.

School of Education. (2005). How to recognize plagiarism. Plagiarism test. Indiana University Bloomington. Retrieved from https://www.indiana.edu/ istd/plagiarism_test.html 


\section{Appendix A. The Understanding of Plagiarism Survey}

This pilot survey aims to assess the lecturer's understanding of the plagiarism concept and the factors affecting it from a wider audience. It is still in the development stage, and therefore the number of items included is more than it should be. Please select only one (1) response to any multiple-choice item. You may give any Qualitative response using either English or Indonesian.

\section{A. Concept of Plagiarism}

1. Have you heard the term "Plagiarism"?
a) Yes
b) No

2. Do you think Plagiarism is different from cheating?
a) Yes
b) No

3. Please give one (1) example of plagiarism practice

4. Plagiarism is a conduct that:
a) Intentionally or unintentionally acknowledges someone's work or idea as your own without recognizing the source properly
b) Intentionally or unintentionally acknowledges someone's work or idea with proper recognition of the source

5. I feel that practicing plagiarism is:
a) accepted since it is not in my academic culture
b) accepted since it is only upheld in western culture
c) not accepted since it violates world-wide academic ethics

6. Do you think cheating is different from plagiarism?
a) Yes
b) No

7. Please give one (1) example of non-plagiarism practice.

8. The definition of plagiarism is:
a) Intentional or unintentional conduct to pass on some parts or a whole of other person's work or idea as your own without giving proper acknowledgment.
b) Intentional or unintentional conduct to pass on some parts or a whole of other person's work or idea as your own with a proper acknowledgment.


9. In my opinion, Plagiarism is:

a) an unrecognized concept in Indonesian academic culture

b) a concept recognized only in Western academic culture

c) an internationally-accepted concept in global academic culture

10. Please indicate whether the following activities are considered as plagiarism by ticking Yes/No on the right columns.

\begin{tabular}{ll}
\hline No & \multicolumn{1}{c}{ Activities } \\
\hline 10.1 & $\begin{array}{l}\text { Referring to word(s), sentences, data, and/or work of other } \\
\text { person without acknowledging it properly }\end{array}$ \\
\hline 10.2 & $\begin{array}{l}\text { Quoting word(s), sentences, data, and/or work of other } \\
\text { person with acknowledging it properly }\end{array}$ \\
\hline 10.3 & $\begin{array}{l}\text { Copying the majority of someone's work, but doing a fair bit } \\
\text { of the work myself }\end{array}$ \\
\hline 10.4 & $\begin{array}{l}\text { Using someone's tables and figures with citation of the } \\
\text { author's name }\end{array}$ \\
\hline 10.5 & $\begin{array}{l}\text { Downloading some parts of or a whole essay from a cheat } \\
\text { site or essay bank on the internet }\end{array}$ \\
\hline 10.6 & $\begin{array}{l}\text { Asking someone to do a work for myself and passing off the } \\
\text { output as my own }\end{array}$ \\
\hline 10.7 & $\begin{array}{l}\text { Reusing idea, words and/or sentences, data and/or } \\
\text { information from my previous own work with proper } \\
\text { acknowledgment }\end{array}$ \\
\hline 10.8 & $\begin{array}{l}\text { Using someone's idea, opinion, view, and/or theory with } \\
\text { proper acknowledgement }\end{array}$ \\
\hline 10.9 & $\begin{array}{l}\text { Paraphrasing word(s) and/or sentences of someone's work } \\
\text { without citing the source properly }\end{array}$ \\
\hline 10.10 & $\begin{array}{l}\text { Copying a few paragraphs of an essay from a book or } \\
\text { Internet site }\end{array}$ \\
\hline 10.11 & $\begin{array}{l}\text { Copying data for a project or research from other sources } \\
\text { without citing the source properly }\end{array}$ \\
\hline 10.12 & $\begin{array}{l}\text { Copying someone's words and/or ideas with citation of the } \\
\text { author's name using a proper quotation technique }\end{array}$ \\
$\begin{array}{l}\text { Getting someone to write a work for myself and } \\
\text { acknowledging it properly on my output }\end{array}$ \\
$\begin{array}{l}\text { Passing off idea, words and/or sentences, data and/or } \\
\text { information from my previous own work as new }\end{array}$ \\
\hline 10.14
\end{tabular}

11. In order to paraphrase, you can express the idea by:

a) Using the same words as given in the original text

b) Using synonyms of the words but still in the same structure as given in the original

c) Using different words and different structure from the original text

12. Have you ever learned or been taught about paraphrasing technique in Indonesian?
a) Yes
b) No 
13. Do you know how to perform paraphrasing in Indonesian?
a) Yes
b) No

14. Have you ever learned or been taught about paraphrasing technique in English?
a) Yes
b) No

15. Do you know how to perform paraphrasing in English?
a) Yes
b) No

16. In paraphrasing ${ }^{1}$, you do the following:
a) Taking someone else's direct words to state their idea
b) Taking someone else's direct words and state their idea by changing few words
c) Taking someone else's direct words and state their idea in your own words

17. Given an excerpt $t^{2}$ below, which of the following options is the most acceptable paraphrased and referenced text?

There is a design methodology called rapid prototyping, which has been used successfully in software engineering. Given similarities between software design and instructional design, we argue that rapid prototyping is a practical method for instructional design, especially for computer-based instruction.

Reference:

Tripp, S. D., \& Bichelmeyer, B. A. (1990). Rapid prototyping: An alternative instructional design strategy. Educational Technology, Research and Development, 38(1), 31-44

Which of the following is the acceptable paraphrased and referenced text?

a) Rapid prototyping is a design methodology that could be used to develop successful and practical computer-based instruction.

b) Rapid prototyping is a design methodology that could be used to successfully develop computer-based instruction (Tripp \& Bichelmeyer, 1990).

c) According to Tripp \& Bichelmeyer (1990), rapid prototyping could be an advantageous methodology for developing innovative computer-based instruction.

d) Rapid prototyping could be an advantageous methodology for developing innovative computer-based instruction.

\footnotetext{
${ }^{1}$ Modified from Alvin Sherman Library (2009) of the Nova Southeastern University, Florida

${ }^{2}$ Adapted from School of Education (2005) of Indiana University at Bloomington.
} 
18. Given an excerpt ${ }^{3}$ below, which of the following options is the most acceptable paraphrased and referenced text?

The technological tools available today for creating computer-based learning materials are incredibly more powerful than those introduced just a few years ago. We can make our own movies with camcorders in our homes; we can publish our own books. Soon teachers and students will be able to use computer-video technology to produce their own learning materials. All it takes is time, know-how, and some funds.

References:

Frick, T. (1991). Restructuring education through technology. Bloomington, IN: Phi Delta Kappa

Educational Foundation.

Which of the following is the acceptable paraphrased and referenced text?

a) The growth of technology has enabled teachers and students to enhance the teaching and learning activities as long as they have adequate supports in terms of time, financial support and knowledge to utilize them (Frick, 1991).

b) Computers are so powerful that K-12 educators and students are now able to produce their own multimedia and Web-based learning materials. They just need to take the time required to learn to use the authoring tools and related technologies such as digital cameras and camcorders.

c) Frick (1991) suggests that powerful technological tools like digital cameras and camcorder can help teachers and students to produce learning materials.

d) Powerful technological tools like digital cameras and camcorder can help teachers and students to produce learning materials as long as they have the time, knowledge and money.

19. Please read the following sample texts, define whether plagiarism occurs in the student versions and give reason of your answer.

\begin{tabular}{|c|c|c|}
\hline \multirow{2}{*}{ No } & \multicolumn{2}{|c|}{ Sample Texts ${ }^{4}$} \\
\hline & Original Version & Student Version \\
\hline 1 & $\begin{array}{l}\text { The concept of systems is really quite simple. } \\
\text { The basic idea is that a system has parts that fit } \\
\text { together to make a whole; but where it gets } \\
\text { complicated - and interesting - is how those } \\
\text { parts are connected or related to each other. } \\
\text { There are many kinds of systems: government }\end{array}$ & $\begin{array}{l}\text { Systems, including both business systems, } \\
\text { and educational systems, are actually very } \\
\text { simple. The main idea is that systems have } \\
\text { parts that fit together to make a whole. What } \\
\text { is interesting is how those parts are } \\
\text { connected together. }\end{array}$ \\
\hline
\end{tabular}
systems, health systems, military systems, business systems, and educational systems, to name a few.

References:

Frick, T. (1991). Restructuring education through technology. Bloomington, IN: Phi Delta Kappa Educational Foundation.

\footnotetext{
${ }^{3}$ Adapted from School of Education (2005) of Indiana University at Bloomington.
}

${ }^{4}$ Adapted from School of Education (2005) of Indiana University at Bloomington. 


\begin{tabular}{clc}
\hline \multirow{2}{*}{ No } & \multicolumn{2}{c}{ Sample Texts $^{4}$} \\
\cline { 2 - 3 } & \multicolumn{1}{c}{ Original Version } & a) Yes \\
\hline Does plagiarism occur here? & b) No \\
\hline
\end{tabular}

Reason of your answer:

2 There is a design methodology called rapid prototyping, which has been used successfully in software engineering. Given similarities between software design and instructional design, we argue that rapid prototyping is a viable method for instructional design, especially for computer-based instruction.

References:

Tripp, S. D., \& Bichelmeyer, B. A. (1990). Rapid prototyping: An alternative instructional design strategy. Educational Technology Research and Development, 38(1), 31-44.

Does plagiarism occur here?

\author{
Rapid prototyping could be an advantageous \\ methodology for developing innovative \\ computer-based instruction (Tripp \& \\ Bichelmeyer, 1990).

\section{References:} \\ Tripp, S. D., \& Bichelmeyer, B. A. (1990). \\ Rapid prototyping: An alternative \\ instructional design strategy. Educational \\ Technology Research and Development, 38(1), \\ 31-44.
}

\section{Reason of your answer:}

3 The study of learning derives from essentially two sources. Because learning involves the acquisition of knowledge, the first concerns the nature of knowledge and how we come to know things.... The second source in which modern learning theory is rooted concerns the nature and representation of mental life.

\section{References:}

Driscoll, M. P. (2000). Psychology of learning for instruction (2nd Ed.). Needham Heights, MA: Allyn \& Bacon.
a) Yes
b) No

The study of learning derives from essentially two sources. The first concerns the nature of knowledge and how we come to know things. The second source concerns the nature and representation of mental life (Driscoll, 2000).

References:

Driscoll, M. P. (2000). Psychology of learning for instruction (2nd Ed.). Needham Heights, MA: Allyn \& Bacon.
Does plagiarism occur here?
a) Yes
b) No

Reason of your answer:

\begin{tabular}{lll}
\hline 4 & The technological tools available today for & Frick (1991) suggests that computers are so \\
creating computer-based learning materials are & powerful today that K-12 educators and \\
incredibly more powerful than those introduced & students are now able to produce their own \\
just a few years ago. We can make our own & multimedia and Web-based learning \\
movies with camcorders in our homes; we can & materials. They just need to take the time \\
publish our own books. Soon teachers and & and some adequate funds required to learn \\
\hline
\end{tabular}




\begin{tabular}{|c|c|c|}
\hline \multirow{2}{*}{ No } & \multicolumn{2}{|c|}{ Sample Texts ${ }^{4}$} \\
\hline & Original Version & Student Version \\
\hline & $\begin{array}{l}\text { students will be able to use computer-video } \\
\text { technology to produce their own learning } \\
\text { materials. All it takes is time, know-how, and } \\
\text { some funds. }\end{array}$ & $\begin{array}{l}\text { to use the authoring tools and related } \\
\text { technologies such as digital cameras and } \\
\text { camcorders. }\end{array}$ \\
\hline & $\begin{array}{l}\text { References: } \\
\text { Frick, T. (1991). Restructuring education } \\
\text { through technology. Bloomington, IN: Phi } \\
\text { Delta Kappa Educational Foundation. }\end{array}$ & $\begin{array}{l}\text { References: } \\
\text { Frick, T. (1991). Restructuring education } \\
\text { through technology. Bloomington, IN: Phi } \\
\text { Delta Kappa Educational Foundation. }\end{array}$ \\
\hline & Does plagiarism occur here? & $\begin{array}{l}\text { a) Yes } \\
\text { b) No }\end{array}$ \\
\hline
\end{tabular}

Reason of your answer:

20. Scenario A: In a class that you are teaching, you find two students submitted almost the same responses for a difficult essay assignment in almost perfect English. Since you know that the English of both students are at low level, what would you do?
a) Ignore it as my time is limited and I understand that the level of difficulty of the essay assignment is high
b) Question both students and give verbal warning
c) Question both students and consult with the authority to give appropriate punishment
d) Question both students and develop anti-plagiarism precautions

21. Scenario B: In a class that you are teaching, you find a clever student submitted a good response of an essay assignment that was submitted to his/her other course last year. What would you do?
a) Ignore it as my time is limited and I acknowledge that this work is his/hers anyway
b) Question the student and give verbal warning
c) Question the student and consult with the authority to give appropriate punishment
d) Question the student and develop anti-plagiarism precautions

22. In your own words, please define Plagiarism (no more than 25 words).

23. In your own words, please define paraphrasing (no more than 25 words).

24. In your own words, please define referencing (no more than 25 words). 
25. Please write down the formal referencing style(s) that your institution normally uses.

26. Have you attended any workshop of Plagiarism?
a) Yes
b) No

27. If you answer Yes for Item \#26 above, when and where did you have it?

28. Have you, in the past, detected any student plagiarism practices during your teaching at your current institution?
a) No, I have not found any plagiarism practices
b) Yes, I have found less than 3 occasions of plagiarism practices
c) Yes, I have found more than 3 occasions of plagiarism practices

29. If you detect a plagiarism practice, what would you do?

30. Have you read the Student Code of Conduct of your current institution?
a) Yes
b) No

31. Have you used any plagiarism detection software provided at your current institution?
a) Yes
b) No

\section{Thank you for participating.}


Appendix B. The codebook of the final set of Understanding of Plagiarism Survey

\begin{tabular}{|c|c|c|c|c|c|}
\hline Variable & Item & Item Type & Code & Details & $\begin{array}{l}\text { Raw } \\
\text { score }\end{array}$ \\
\hline \multirow[t]{3}{*}{$\mathrm{A} 3$} & \multirow[t]{3}{*}{$\begin{array}{l}\text { Please give one (1) example of } \\
\text { plagiarism practice }\end{array}$} & \multirow[t]{3}{*}{ Open-Ended } & 1 & $\begin{array}{l}\text { If a correct response is } \\
\text { given }\end{array}$ & 1 \\
\hline & & & 0 & $\begin{array}{l}\text { If an incorrect response is } \\
\text { given, or no response }\end{array}$ & 0 \\
\hline & & & 2 & (2) No & 0 \\
\hline \multirow[t]{3}{*}{ A7 } & \multirow[t]{3}{*}{$\begin{array}{l}\text { Please one (1) example of non- } \\
\text { plagiarism practice }\end{array}$} & \multirow[t]{3}{*}{ Open-Ended } & 1 & $\begin{array}{l}\text { If a correct response is } \\
\text { given }\end{array}$ & 1 \\
\hline & & & 0 & $\begin{array}{l}\text { If an incorrect response is } \\
\text { given, or no response }\end{array}$ & 0 \\
\hline & & & 2 & (2) No & 0 \\
\hline \multirow[t]{2}{*}{ A10.2 } & \multirow{2}{*}{$\begin{array}{l}\text { Quoting word(s), sentences, data, } \\
\text { and/or work of other person } \\
\text { with acknowledging it properly }\end{array}$} & \multirow{2}{*}{$\begin{array}{l}\text { Multiple- } \\
\text { Choice }\end{array}$} & 1 & (1) Yes & 0 \\
\hline & & & 2 & (2) No & 1 \\
\hline \multirow[t]{2}{*}{ A10.4 } & \multirow{2}{*}{$\begin{array}{l}\text { Using someone's tables and } \\
\text { figures with citation of the } \\
\text { author's name }\end{array}$} & \multirow{2}{*}{$\begin{array}{l}\text { Multiple- } \\
\text { Choice }\end{array}$} & 1 & (1) Yes & 0 \\
\hline & & & 2 & (2) No & 1 \\
\hline \multirow[t]{2}{*}{ A10.5 } & \multirow{2}{*}{$\begin{array}{l}\text { Downloading some parts of or a } \\
\text { whole essay from a cheat site or } \\
\text { essay bank on the internet }\end{array}$} & \multirow{2}{*}{$\begin{array}{l}\text { Multiple- } \\
\text { Choice }\end{array}$} & 1 & (1) Yes & 1 \\
\hline & & & 2 & (2) No & 0 \\
\hline \multirow[t]{2}{*}{ A10.6 } & \multirow{2}{*}{$\begin{array}{l}\text { Asking someone to do a work for } \\
\text { myself and passing off the output } \\
\text { as my own }\end{array}$} & \multirow{2}{*}{$\begin{array}{l}\text { Multiple- } \\
\text { Choice }\end{array}$} & 1 & (1) Yes & 1 \\
\hline & & & 2 & (2) No & 0 \\
\hline \multirow[t]{2}{*}{ A10.7 } & \multirow{2}{*}{$\begin{array}{l}\text { Reusing idea, words and/or } \\
\text { sentences, data and/or } \\
\text { information from my previous } \\
\text { own work with proper } \\
\text { acknowledgment }\end{array}$} & \multirow{2}{*}{$\begin{array}{l}\text { Multiple- } \\
\text { Choice }\end{array}$} & 1 & (1) Yes & 0 \\
\hline & & & 2 & (2) No & 1 \\
\hline \multirow[t]{2}{*}{ A10.9 } & \multirow{2}{*}{$\begin{array}{l}\text { Paraphrasing word(s) and/or } \\
\text { sentences of someone's work } \\
\text { without citing the source } \\
\text { properly }\end{array}$} & \multirow{2}{*}{$\begin{array}{l}\text { Multiple- } \\
\text { Choice }\end{array}$} & 1 & (1) Yes & 1 \\
\hline & & & 2 & (2) No & 0 \\
\hline \multirow[t]{2}{*}{ A10.10 } & \multirow{2}{*}{$\begin{array}{l}\text { Copying a few paragraphs of an } \\
\text { essay from a book or Internet site }\end{array}$} & \multirow{2}{*}{$\begin{array}{l}\text { Multiple- } \\
\text { Choice }\end{array}$} & 1 & (1) Yes & 1 \\
\hline & & & 2 & (2) No & 0 \\
\hline \multirow[t]{2}{*}{ A10.12 } & \multirow{2}{*}{$\begin{array}{l}\text { Copying someone's words } \\
\text { and/or ideas with citation of the } \\
\text { author's name using a proper } \\
\text { quotation technique }\end{array}$} & \multirow{2}{*}{$\begin{array}{l}\text { Multiple- } \\
\text { Choice }\end{array}$} & 1 & (1) Yes & 0 \\
\hline & & & 2 & (2) No & 1 \\
\hline \multirow[t]{2}{*}{ A10.13 } & \multirow{2}{*}{$\begin{array}{l}\text { Getting someone to write a work } \\
\text { for myself and acknowledging it } \\
\text { properly on my output }\end{array}$} & Multiple- & 1 & (1) Yes & 0 \\
\hline & & Choice & 2 & (2) No & 1 \\
\hline A10.14 & Passing off idea, words and/or & Multiple- & 1 & (1) Yes & 1 \\
\hline & $\begin{array}{l}\text { sentences, data and/or } \\
\text { information from my previous } \\
\text { own work as new }\end{array}$ & Choice & 2 & (2) No & 0 \\
\hline A11 & $\begin{array}{l}\text { In order to paraphrase, you can } \\
\text { express the idea by: }\end{array}$ & $\begin{array}{l}\text { Multiple- } \\
\text { Choice }\end{array}$ & 1 & $\begin{array}{l}\text { (1) Using the same } \\
\text { words as given in the } \\
\text { original text }\end{array}$ & 0 \\
\hline & & & 2 & $\begin{array}{l}\text { (2) Using synonyms of } \\
\text { the words but still in the } \\
\text { same structure as given in } \\
\text { the original }\end{array}$ & 1 \\
\hline
\end{tabular}




\begin{tabular}{|c|c|c|c|c|c|}
\hline Variable & Item & Item Type & Code & Details & $\begin{array}{l}\text { Raw } \\
\text { score }\end{array}$ \\
\hline & & & 3 & $\begin{array}{l}\text { (3) Using different words } \\
\text { and different structure } \\
\text { from the original text }\end{array}$ & 2 \\
\hline \multirow[t]{3}{*}{ A16 } & \multirow[t]{3}{*}{$\begin{array}{l}\text { In paraphrasing, you do the } \\
\text { following: }\end{array}$} & \multirow[t]{3}{*}{$\begin{array}{l}\text { Multiple- } \\
\text { Choice }\end{array}$} & 1 & $\begin{array}{l}\text { (1) Taking someone } \\
\text { else's direct words to } \\
\text { state their idea }\end{array}$ & 0 \\
\hline & & & 2 & $\begin{array}{l}\text { (2) Taking someone } \\
\text { else's direct words and } \\
\text { state their idea by } \\
\text { changing few words }\end{array}$ & 1 \\
\hline & & & 3 & $\begin{array}{l}\text { (3) Taking someone else's } \\
\text { direct words and state } \\
\text { their idea in your own } \\
\text { words }\end{array}$ & 2 \\
\hline \multirow[t]{5}{*}{ A17 } & \multirow{5}{*}{$\begin{array}{l}\text { Given an excerpt below, which } \\
\text { of the following options is the } \\
\text { most acceptable paraphrased and } \\
\text { referenced text? } \\
\text { There is a design methodology } \\
\text { called rapid prototyping, which } \\
\text { has been used successfully in } \\
\text { software engineering. Given } \\
\text { similarities between software } \\
\text { design and instructional design, } \\
\text { we argue that rapid prototyping is } \\
\text { a practical method for } \\
\text { instructional design, especially for } \\
\text { computer-based instruction. } \\
\text { Reference: } \\
\text { Tripp, S. D., \& Bichelmeyer, B. } \\
\text { A. (1990). Rapid prototyping: An } \\
\text { alternative instructional design } \\
\text { strategy. Educational Technology, } \\
\text { Research and Development, } \\
\text { 38(1), 31-44 }\end{array}$} & \multirow[t]{5}{*}{$\begin{array}{l}\text { Multiple- } \\
\text { Choice }\end{array}$} & \multirow[t]{2}{*}{1} & \multirow{2}{*}{$\begin{array}{l}\text { (1) Rapid prototyping is } \\
\text { a design methodology } \\
\text { that could be used to } \\
\text { develop successful and } \\
\text { practical computer-based } \\
\text { instruction. }\end{array}$} & \multirow[t]{2}{*}{0} \\
\hline & & & & & \\
\hline & & & 2 & $\begin{array}{l}\text { (2) Rapid prototyping is } \\
\text { a design methodology } \\
\text { that could be used to } \\
\text { successfully develop } \\
\text { computer-based } \\
\text { instruction (Tripp \& } \\
\text { Bichelmeyer, 1990). }\end{array}$ & 2 \\
\hline & & & 3 & $\begin{array}{l}\text { (3) According to Tripp } \\
\text { \& Bichelmeyer (1990), } \\
\text { rapid prototyping could } \\
\text { be an advantageous } \\
\text { methodology for } \\
\text { developing innovative } \\
\text { computer-based } \\
\text { instruction. }\end{array}$ & 3 \\
\hline & & & 4 & $\begin{array}{l}\text { (4) Rapid prototyping } \\
\text { could be an advantageous } \\
\text { methodology for } \\
\text { developing innovative } \\
\text { computer-based } \\
\text { instruction }\end{array}$ & 1 \\
\hline \multirow[t]{3}{*}{ A18 } & $\begin{array}{l}\text { Given an excerpt below, which } \\
\text { of the following options is the } \\
\text { most acceptable paraphrased and } \\
\text { referenced text? }\end{array}$ & \multirow[t]{3}{*}{$\begin{array}{l}\text { Multiple- } \\
\text { Choice }\end{array}$} & \multirow[t]{2}{*}{1} & \multirow{2}{*}{$\begin{array}{l}\text { (1) The growth of } \\
\text { technology has enabled } \\
\text { teachers and students to } \\
\text { enhance the teaching and } \\
\text { learning activities as long } \\
\text { as they have adequate } \\
\text { supports in terms of time, } \\
\text { financial support and } \\
\text { knowledge to utilize them } \\
\text { (Frick, 1991). }\end{array}$} & \multirow[t]{2}{*}{3} \\
\hline & $\begin{array}{l}\text { The technological tools available } \\
\text { today for creating computer- } \\
\text { based learning materials are } \\
\text { incredibly more powerful than } \\
\text { those introduced just a few years } \\
\text { ago. We can make our own }\end{array}$ & & & & \\
\hline & $\begin{array}{l}\text { movies with camcorders in our } \\
\text { homes; we can publish our own } \\
\text { books. Soon teachers and } \\
\text { students will be able to use } \\
\text { computer-video technology to }\end{array}$ & & 2 & $\begin{array}{l}\text { (2) Computers are so } \\
\text { powerful that K-12 } \\
\text { educators and students } \\
\text { are now able to produce } \\
\text { their own multimedia }\end{array}$ & 1 \\
\hline
\end{tabular}




\begin{tabular}{|c|c|c|c|c|c|}
\hline Variable & Item & Item Type & Code & Details & $\begin{array}{l}\text { Raw } \\
\text { score }\end{array}$ \\
\hline & \multirow[t]{3}{*}{$\begin{array}{l}\text { produce their own learning } \\
\text { materials. All it takes is time, } \\
\text { know-how, and some funds. } \\
\text { References: } \\
\text { Frick, T. (1991). Restructuring } \\
\text { education through technology. } \\
\text { Bloomington, IN: Phi Delta } \\
\text { Kappa Educational Foundation. }\end{array}$} & & & $\begin{array}{l}\text { and Web-based learning } \\
\text { materials. They just need } \\
\text { to take the time required } \\
\text { to learn to use the } \\
\text { authoring tools and } \\
\text { related technologies such } \\
\text { as digital cameras and } \\
\text { camcorders. }\end{array}$ & \\
\hline & & & 3 & $\begin{array}{l}\text { (3) Frick (1991) suggests } \\
\text { that powerful } \\
\text { technological tools like } \\
\text { digital cameras and } \\
\text { camcorder can help } \\
\text { teachers and students to } \\
\text { produce learning } \\
\text { materials. }\end{array}$ & 2 \\
\hline & & & 4 & $\begin{array}{l}\text { (4) Powerful } \\
\text { technological tools like } \\
\text { digital cameras and } \\
\text { camcorder can help } \\
\text { teachers and students to } \\
\text { produce learning } \\
\text { materials as long as they } \\
\text { have the time, knowledge } \\
\text { and money }\end{array}$ & 0 \\
\hline
\end{tabular}

\begin{tabular}{|c|c|c|c|c|c|}
\hline \multirow[t]{2}{*}{ A19.1.1 } & \multirow[t]{2}{*}{ Does plagiarism occur here? } & \multirow{2}{*}{$\begin{array}{l}\text { Multiple- } \\
\text { Choice }\end{array}$} & 1 & (1) Yes & 1 \\
\hline & & & 2 & (2) No & 0 \\
\hline \multirow[t]{2}{*}{ A19.1.2 } & \multirow[t]{2}{*}{ Reasons } & \multirow[t]{2}{*}{ Open-Ended } & 1 & $\begin{array}{l}\text { If a correct reason is } \\
\text { given: There's no } \\
\text { reference }\end{array}$ & 1 \\
\hline & & & 0 & $\begin{array}{l}\text { If an incorrect reason is } \\
\text { given, or no response }\end{array}$ & 0 \\
\hline \multirow[t]{2}{*}{ A19.2.1 } & \multirow[t]{2}{*}{ Does plagiarism occur here? } & \multirow{2}{*}{$\begin{array}{l}\text { Multiple- } \\
\text { Choice }\end{array}$} & 1 & (1) Yes & 0 \\
\hline & & & 2 & (2) No & 1 \\
\hline \multirow[t]{3}{*}{ A19.2.2 } & \multirow[t]{3}{*}{ Reasons } & \multirow[t]{3}{*}{ Open-Ended } & 2 & $\begin{array}{l}\text { If } 2 \text { correct reasons are } \\
\text { given: The paragraph is } \\
\text { well-paraphrased \& } \\
\text { referenced }\end{array}$ & 2 \\
\hline & & & 1 & $\begin{array}{l}\text { If only } 1 \text { correct reason is } \\
\text { given: Either it is well- } \\
\text { paraphrased OR } \\
\text { referenced }\end{array}$ & 1 \\
\hline & & & 0 & $\begin{array}{l}\text { If an incorrect reason is } \\
\text { given, or no response }\end{array}$ & 0 \\
\hline \multirow[t]{2}{*}{ A19.3.1 } & \multirow[t]{2}{*}{ Does plagiarism occur here? } & \multirow{2}{*}{$\begin{array}{l}\text { Multiple- } \\
\text { Choice }\end{array}$} & 1 & (1) Yes & 1 \\
\hline & & & 2 & (2) No & 0 \\
\hline \multirow[t]{2}{*}{ A19.3.2 } & \multirow[t]{2}{*}{ Reasons } & \multirow[t]{2}{*}{ Open-Ended } & 1 & $\begin{array}{l}\text { If a correct reason is } \\
\text { given: It's a direct copy of } \\
\text { several words }\end{array}$ & 1 \\
\hline & & & 0 & $\begin{array}{l}\text { If an incorrect reason is } \\
\text { given, or no response }\end{array}$ & 0 \\
\hline \multirow[t]{2}{*}{ A19.4.1 } & \multirow[t]{2}{*}{ Does plagiarism occur here? } & \multirow{2}{*}{$\begin{array}{l}\text { Multiple- } \\
\text { Choice }\end{array}$} & 1 & (1) Yes & 0 \\
\hline & & & 2 & (2) No & 1 \\
\hline
\end{tabular}




\begin{tabular}{|c|c|c|c|c|c|}
\hline Variable & Item & Item Type & Code & Details & $\begin{array}{l}\text { Raw } \\
\text { score }\end{array}$ \\
\hline \multirow[t]{3}{*}{ A19.4.2 } & \multirow[t]{3}{*}{ Reasons } & \multirow[t]{3}{*}{ Open-Ended } & 2 & $\begin{array}{l}\text { If } 2 \text { correct reasons are } \\
\text { given: The paragraph is } \\
\text { well-paraphrased \& } \\
\text { referenced }\end{array}$ & 2 \\
\hline & & & 1 & $\begin{array}{l}\text { If only } 1 \text { correct reason is } \\
\text { given: Either it is well- } \\
\text { paraphrased OR } \\
\text { referenced }\end{array}$ & 1 \\
\hline & & & 0 & $\begin{array}{l}\text { If an incorrect reason is } \\
\text { given, or no response }\end{array}$ & 0 \\
\hline \multirow[t]{4}{*}{ A20 } & \multirow{4}{*}{$\begin{array}{l}\text { Scenario A: In a class that you } \\
\text { are teaching, you find two } \\
\text { students submitted almost the } \\
\text { same responses for a difficult } \\
\text { essay assignment in almost } \\
\text { perfect English. Since you know } \\
\text { that the English of both students } \\
\text { are at low level, what would you } \\
\text { do? }\end{array}$} & \multirow[t]{4}{*}{$\begin{array}{l}\text { Multiple- } \\
\text { Choice }\end{array}$} & 1 & $\begin{array}{l}\text { (1) Ignore it as my time } \\
\text { is limited and I } \\
\text { understand that the level } \\
\text { of difficulty of the essay } \\
\text { assignment is high }\end{array}$ & 0 \\
\hline & & & 2 & $\begin{array}{l}\text { (2) Question both } \\
\text { students and give verbal } \\
\text { warning }\end{array}$ & 1 \\
\hline & & & 3 & $\begin{array}{l}\text { (3) Question both } \\
\text { students and consult with } \\
\text { the authority to give } \\
\text { appropriate punishment }\end{array}$ & 3 \\
\hline & & & 4 & $\begin{array}{l}\text { (4) Question both } \\
\text { students and develop } \\
\text { anti-plagiarism } \\
\text { precautions }\end{array}$ & 2 \\
\hline \multirow[t]{4}{*}{ A21 } & \multirow{4}{*}{$\begin{array}{l}\text { Scenario B: In a class that you } \\
\text { are teaching, you find a clever } \\
\text { student submitted a good } \\
\text { response of an essay assignment } \\
\text { that was submitted to his/her } \\
\text { other course last year. What } \\
\text { would you do? }\end{array}$} & \multirow[t]{4}{*}{$\begin{array}{l}\text { Multiple- } \\
\text { Choice }\end{array}$} & 1 & $\begin{array}{l}\text { (1) Ignore it as my time } \\
\text { is limited and I } \\
\text { acknowledge that this } \\
\text { work is his/hers anyway }\end{array}$ & 0 \\
\hline & & & 2 & $\begin{array}{l}\text { (2) Question the student } \\
\text { and give verbal warning }\end{array}$ & 1 \\
\hline & & & 3 & $\begin{array}{l}\text { (3) Question the student } \\
\text { and consult with the } \\
\text { authority to give } \\
\text { appropriate punishment }\end{array}$ & 3 \\
\hline & & & 4 & $\begin{array}{l}\text { (4) Question the student } \\
\text { and develop anti- } \\
\text { plagiarism precautions }\end{array}$ & 2 \\
\hline
\end{tabular}

